4

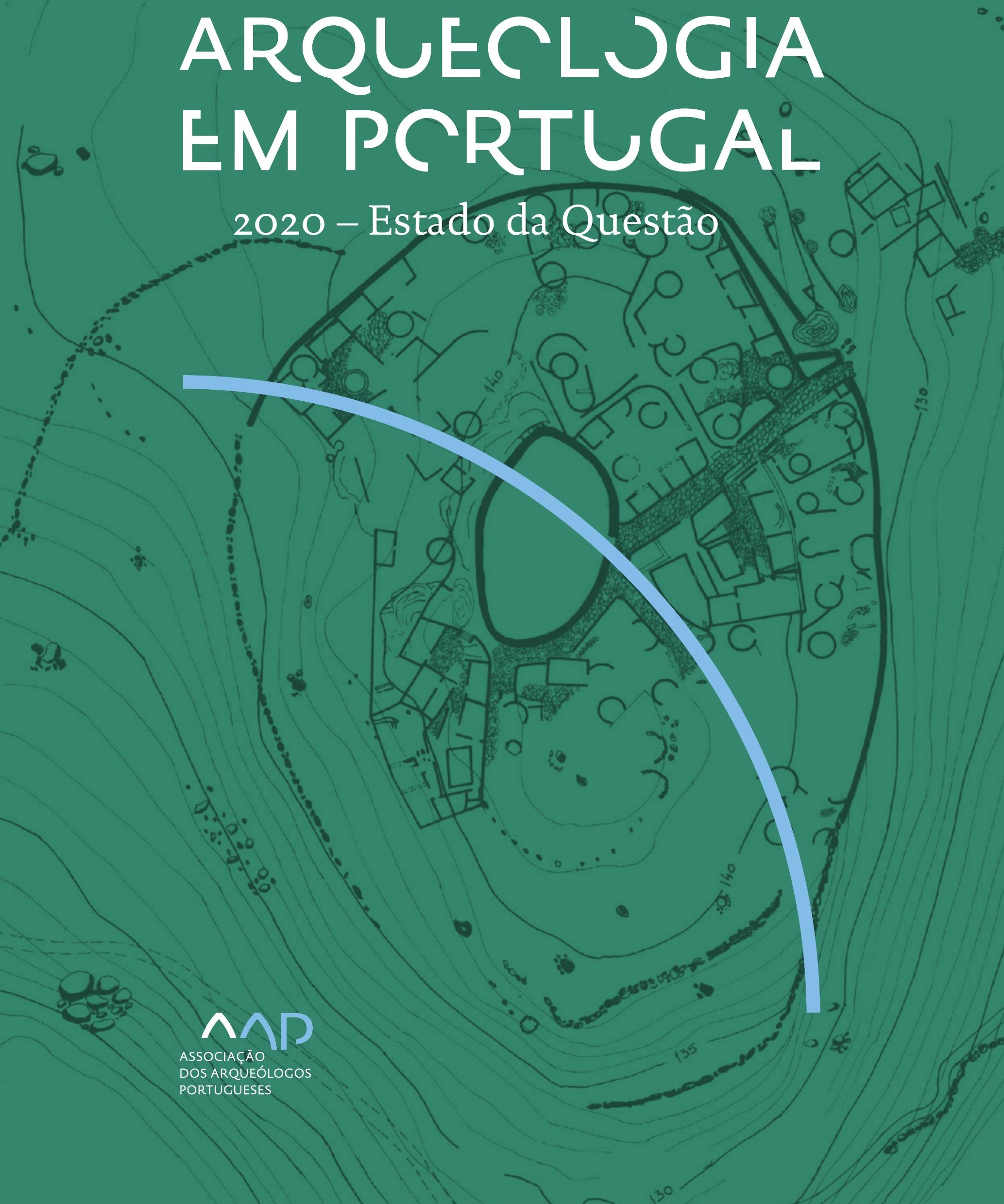


Coordenação editorial: José Morais Arnaud, César Neves e Andrea Martins Design gráfico: Flatland Design

AAP - ISBN: 978-972-9451-89-8

CITCEM - ISBN: 978-989-8970-25-1

Associação dos Arqueólogos Portugueses e CITCEM

Lisboa, 2020

O conteúdo dos artigos é da inteira responsabilidade dos autores. Sendo assim a Associação dos Arqueólogos Portugueses declina qualquer responsabilidade por eventuais equívocos ou questões de ordem ética e legal.

Desenho de capa:

Planta do castro de Monte Mozinho (Museu Municipal de Penafiel).

\section{$\hat{\wedge} \mathrm{P}$}

DOS ARQUEÓLOGOS PORTUGUESES

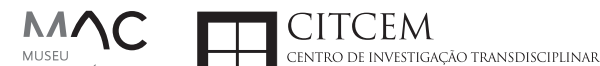
MUSEU
ARQUELLÓGICO
DO CARMO
U.PORTO

FLUP FACULDADE DE LETRAS
UNIVERSIDADE DO PORTO

Apoio

EC para a Ciência 


\section{Índice}

15 Prefácio

José Morais Arnaud

\section{Historiografia e Teoria}

17 Território, comunidade, memória e emoção: a contribuição da história da arqueologia (algumas primeiras e breves reflexões)

Ana Cristina Martins

25 Como descolonizar a arqueologia portuguesa?

Rui Gomes Coelho

41 Arqueologia e Modernidade: uma revisitação pessoal e breve de alguns aspetos da obra homónima de Julian Thomas de 2004

Vítor Oliveira Jorge

57 Dados para a História das Mulheres na Arqueologia portuguesa, dos finais do século XIX aos inícios do século XX: números, nomes e tabelas

Filipa Dimas / Mariana Diniz

73 Retractos da arqueologia portuguesa na imprensa: (in)visibilidades no feminino

Catarina Costeira / Elsa Luís

85 Arqueologia e Arqueólogos no Norte de Portugal Jacinta Bugalhão

101 Vieira Guimarães (1864-1939) e a arqueologia em Tomar: uma abordagem sobre o território e as gentes

João Amendoeira Peixoto / Ana Cristina Martins

115 Os memoráveis? A arqueologia algarvia na imprensa nacional e regional na presente centúria (2001-2019): características, visões do(s) passado(s) e a arqueologia

enquanto marca

Frederico Agosto / João Silva

129 A Evolução da Arqueologia Urbana e a Valorização Patrimonial no Barlavento Algarvio: Os casos de Portimão e Silves

Artur Mateus / Diogo Varandas / Rafael Boavida

\section{Gestão, Valorização e Salvaguarda do Património}

145 O Caderno Reivindicativo e as condições de trabalho em Arqueologia Miguel Rocha / Liliana Matias Carvalho / Regis Barbosa / Mauro Correia / Sara Simões / Jacinta Bugalhão / Sara Brito / Liliana Veríssimo Carvalho / Richard Peace / Pedro Peça / Cézer Santos

155 Os Estudos de Impacte Patrimonial como elemento para uma estratégia sustentável de minimização de impactes no âmbito de reconversões agrícolas Tiago do Pereiro

165 Salvaguarda de Património arqueológico em operações florestais: gestão e sensibilização Filipa Bragança / Gertrudes Zambujo / Sandra Lourenço / Belém Paiva / Carlos Banha / Frederico Tatá Regala / Helena Moura / Jacinta Bugalhão / João Marques / José Correia / Pedro Faria / Samuel Melro

179 Os valores do Património: uma investigação sobre os Sítios Pré-históricos de Arte Rupestre do Vale do Rio Côa e de Siega Verde José Paulo Francisco 
189 Conjugando recursos arqueológicos e naturais para potenciar as visitas ao Geoparque Litoral de Viana do Castelo (Noroeste de Portugal)

Hugo A. Sampaio / Ana M.S. Bettencourt / Susana Marinho / Ricardo Carvalhido

203 Áreas de Potencial Arqueológico na Região do Médio Tejo: Modelo Espacial Preditivo Rita Ferreira Anastácio / Ana Filipa Martins / Luiz Oosterbeek

223 Património Arqueológico e Gestão Territorial: O contributo da Arqueologia para a revisão do PDM de Avis

Ana Cristina Ribeiro

237 A coleção arqueológica do extinto Museu Municipal do Porto - Origens, Percursos e Estudos

Sónia Couto

251 Valpaços - uma nova carta arqueológica

Pedro Pereira / Maria de Fátima Casares Machado

263 Arqueologia na Cidade de Peniche

Adriano Constantino / Luís Rendeiro

273 Arqueologia Urbana: a cidade de Lagos como caso de Estudo Cátia Neto

285 Estratégias de promoção do património cultural subaquático nos Açores. O caso da ilha do Faial

José Luís Neto / José Bettencourt / Luís Borges / Pedro Parreira

297 Carta Arqueológica da Cidade Velha: Uma primeira abordagem

Jaylson Monteiro / Nireide Tavares / Sara da Veiga / Claudino Ramos / Edson Brito /

Carlos Carvalho / Francisco Moreira / Adalberto Tavares

311 Antropologia Virtual: novas metodologias para a análise morfológica e funcional Ricardo Miguel Godinho / Célia Gonçalves

\section{Didáctica da Arqueologia}

327 Como os projetos de Arqueologia podem contribuir para uma comunidade culturalmente mais consciente Alexandra Figueiredo / Claúdio Monteiro / Adolfo Silveira / Ricardo Lopes

337 Educação Patrimonial - Um cidadão esclarecido é um cidadão ativo! Ana Paula Almeida

351 A aproximação da Arqueologia à sala de aula: um caso de estudo no $3^{\circ}$ ciclo do Ensino Básico Luís Serrão Gil

363 Arqueologia 3.o - Pensar e comunicar a Arqueologia para um futuro sustentável Mónica Rolo

377 “Conversa de Arqueólogos" - Divulgar a Arqueologia em tempos de Pandemia Diogo Teixeira Dias

389 Escola Profissional de Arqueologia: desafios e oportunidades Susana Nunes / Dulcineia Pinto / Júlia Silva / Ana Mascarenhas

399 Os Museus de Arqueologia e os Jovens: a oferta educativa para o público adolescente Beatriz Correia Barata / Leonor Medeiros

411 O museu universitário como mediador entre a ciência e a sociedade: o exemplo da secção de arqueologia no Museu de História Natural e da Ciência da Universidade do Porto (MHNC-UP)

Rita Gaspar 
421 Museu de Lanifícios: Real Fábrica de Panos. Atividades no âmbito da Arqueologia Beatriz Correia Barata / Rita Salvado

427 Arqueologia Pública e o caso da localidade da Mata (Torres Novas) Cláudia Manso / Ana Rita Ferreira / Cristiana Ferreira / Vanessa Cardoso Antunes

431 Do sítio arqueológico ao museu: um percurso (também) didático Lídia Fernandes

447 Estão todos convidados para a Festa! E para dançar também... O projecto do Serviço Educativo do Museu Arqueológico do Carmo na $5^{\underline{a}}$ Edição da Festa da Arqueologia Rita Pires dos Santos

459 O “Clã de Carenque”, um projeto didático de arqueologia Eduardo Gonzalez Rocha

469 Mediação cultural: peixe que puxa carroça nas Ruínas Romanas de Troia Inês Vaz Pinto / Ana Patrícia Magalhães / Patrícia Brum / Filipa Santos

481 Didática Arqueológica, experiências do Projeto Mértola Vila Museu Maria de Fátima Palma / Clara Rodrigues / Susana Gómez / Lígia Rafael

\section{Arte Rupestre}

497 Os inventários de arte rupestre em Portugal Mila Simões de Abreu

513 O projeto FIRST-ART - conservação, documentação e gestão das primeiras manifestações de arte rupestre no Sudoeste da Península Ibérica: as grutas do Escoural e Maltravieso Sara Garcês / Hipólito Collado / José Julio García Arranz / Luiz Oosterbeek / António Carlos Silva / Pierluigi Rosina / Hugo Gomes / Anabela Borralheiro Pereira / George Nash / Esmeralda Gomes / Nelson Almeida / Carlos Carpetudo

523 Trabalhos de documentação de arte paleolítica realizados no âmbito do projeto PalæoCôa André Tomás Santos / António Fernando Barbosa / Luís Luís / Marcelo Silvestre / Thierry Aubry

537 Imagens fantasmagóricas, silhuetas elusivas: as figuras humanas na arte do Paleolítico Superior da região do Côa Mário Reis

$55^{1}$ Os motivos zoomórficos representados nas placas de tear de Vila Nova de São Pedro (Azambuja, Portugal) Andrea Martins / César Neves / José M. Arnaud / Mariana Diniz

571 Arte Rupestre do Monte de Góios (Lanhelas, Caminha). Síntese dos resultados dos trabalhos efectuados em 2007-2009 Mário Varela Gomes

599 Gravuras rupestres de barquiformes no Monte de S. Romão, Guimarães, Noroeste de Portugal Daniela Cardoso

613 Círculos segmentados gravados na Bacia do Rio Lima (Noroeste de Portugal): contributos para o seu estudo Diogo Marinho / Ana M.S. Bettencourt / Hugo Aluai Sampaio

631 Equídeos gravados no curso inferior do Rio Mouro, Monção (NW Portugal). Análise preliminar Coutinho, L.M. / Bettencourt, A.M.S / Sampaio, Hugo A.S

645 Paletas na Arte Rupestre do Noroeste de Portugal. Inventário preliminar Bruna Sousa Afonso / Ana M. S. Bettencourt / Hugo A. Sampaio 


\section{Pré-História}

661 O projeto Miño/Minho: balanço de quatro anos de trabalhos arqueológicos Sérgio Monteiro-Rodrigues / João Pedro Cunha-Ribeiro / Eduardo Méndez-Quintas / Carlos Ferreira / Pedro Xavier / José Meireles / Alberto Gomes / Manuel Santonja / Alfredo Pérez-González

677 A ocupação paleolítica da margem esquerda do Baixo Minho: a indústria lítica do sítio de Pedreiras 2 (Monção, Portugal) e a sua integração no contexto regional Carlos Ferreira / João Pedro Cunha-Ribeiro / Sérgio Monteiro-Rodrigues / Eduardo Méndez-Quintas / Pedro Xavier / José Meireles / Alberto Gomes / Manuel Santonja / Alfredo Pérez-González

693 O sítio acheulense do Plistocénico médio da Gruta da Aroeira Joan Daura / Montserrat Sanz / Filipa Rodrigues / Pedro Souto / João Zilhão

703 As sociedades neandertais no Barlavento algarvio: modelos preditivos com recurso aos SIG

Daniela Maio

715 A utilização de quartzo durante o Paleolítico Superior no território dos vales dos rios Vouga e Côa

Cristina Gameiro / Thierry Aubry / Bárbara Costa / Sérgio Gomes / Luís Luís / Carmen Manzano / André Tomás Santos

733 Uma perspetiva diacrónica da ocupação do concheiro do Cabeço da Amoreira (Muge, Portugal) a partir da tecnologia lítica Joana Belmiro / João Cascalheira / Célia Gonçalves

745 Novos dados sobre a Pré-história Antiga no concelho de Palmela. A intervenção arqueológica no sítio do Poceirão I

Michelle Teixeira Santos

757 Problemas em torno de Datas Absolutas Pré-Históricas no Norte do Alentejo Jorge de Oliveira

771 Povoamento pré-histórico nas áreas montanhosas do NO de Portugal: o Abrigo 1 de Vale de Cerdeira Pedro Xavier / José Meireles / Carlos Alves

783 Apreciação do povoamento do Neolítico Inicial na Baixa Bacia do Douro. A Lavra I (Serra da Aboboreira) como caso de estudo Maria de Jesus Sanches

797 O Processo de Neolitização na Plataforma do Mondego: os dados do Sector C do Outeiro dos Castelos de Beijós (Carregal do Sal)

João Carlos de Senna-Martinez / José Manuel Quintã Ventura / Andreia Carvalho / Cíntia Maurício

823 Novos trabalhos na Lapa da Bugalheira (Almonda, Torres Novas) Filipa Rodrigues / Pedro Souto / Artur Ferreira / Alexandre Varanda / Luís Gomes / Helena Gomes / João Zilhão

837 A pedra polida e afeiçoada do sítio do Neolítico médio da Moita do Ourives (Benavente, Portugal)

César Neves

857 Casal do Outeiro (Encarnação, Mafra): novos contributos para o conhecimento do povoamento do Neolítico final na Península de Lisboa.

Cátia Delicado / Carlos Maneira e Costa / Marta Miranda / Ana Catarina Sousa

873 Stresse infantil, morbilidade e mortalidade no sítio arqueológico do Neolítico Final/ Calcolítico ( $4^{\circ}$ e $3^{\circ}$ milénio a.C.) do Monte do Carrascal 2 (Ferreira do Alentejo, Beja) Liliana Matias de Carvalho / Sofia N. Wasterlain 
885 Come together: O Conjunto Megalítico das Motas (Monção, Viana do Castelo) e as expressões Campaniformes do Alto Minho Ana Catarina Basílio / Rui Ramos

899 Trabalhos arqueológicos no sítio Calcolítico da Pedreira do Poio Carla Magalhães / João Muralha / Mário Reis / António Batarda Fernandes

913 O sítio arqueológico de Castanheiro do Vento. Da arquitectura do sítio à arquitectura de um território João Muralha Cardoso

925 Estudo zooarqueológico das faunas do Calcolítico final de Vila Nova de São Pedro (Azambuja, Portugal): Campanhas de 2017 e 2018 Cleia Detry / Ana Catarina Francisco / Mariana Diniz / Andrea Martins / César Neves / José Morais Arnaud

943 As faunas depositadas no Museu Arqueológico do Carmo provenientes de Vila Nova de São Pedro (Azambuja): as campanhas de 1937 a 1967 Ana Catarina Francisco / Cleia Detry / César Neves / Andrea Martins / Mariana Diniz / José Morais Arnaud

959 Análise funcional de material lítico em sílex do castro de Vila Nova de S. Pedro (Azambuja, Portugal): uma primeira abordagem Rafael Lima

971 O recinto da Folha do Ouro 1 (Serpa) no contexto dos recintos de fossos calcolíticos alentejanos

António Carlos Valera / Tiago do Pereiro / Pedro Valério / António M. Monge Soares

\section{Proto-História}

987 Produção de sal marinho na Idade do Bronze do noroeste Português. Alguns dados para uma reflexão

Ana M. S. Bettencourt / Sara Luz / Nuno Oliveira / Pedro P. Simões / Maria Isabel C. Alves / Emílio Abad-Vidal

1001 A estátua-menir do Pedrão ou de São Bartolomeu do Mar (Esposende, noroeste de Portugal) no contexto arqueológico da fachada costeira de entre os rios Neiva e Cávado Ana M. S. Bettencourt / Manuel Santos-Estévez / Pedro Pimenta Simões / Luís Gonçalves

1015 O Castro do Muro (Vandoma/Baltar, Paredes) - notas para uma biografia de ocupação da Idade do Bronze à Idade Média

Maria Antónia D. Silva / Ana M. S. Bettencourt / António Manuel S. P. Silva / Natália Félix

1031 Do Bronze Final à Idade Média - continuidades e hiatos na ocupação de Povoados em Oliveira de Azeméis João Tiago Tavares / Adriaan de Man

1041 As faunas do final da Idade do Bronze no Sul de Portugal: leituras desde o Outeiro do Circo (Beja)

Nelson J. Almeida / Íris Dias / Cleia Detry / Eduardo Porfírio / Miguel Serra

1055 A Espada do Monte das Oliveiras (Serpa) - uma arma do Bronze Pleno do Sudoeste Rui M. G. Monge Soares / Pedro Valério / Mariana Nabais / António M. Monge Soares

1065 São Julião da Branca (Albergaria-a-Velha) - Investigação e valorização de um povoado do Bronze Final

António Manuel S. P. Silva / Paulo A. P. Lemos / Sara Almeida e Silva / Edite Martins de Sá

1083 Do castro de S. João ao Mosteiro de Santa Clara: notícia de uma intervenção arqueológica, em Vila do Conde Rui Pinheiro 
1095 O castro de Ovil (Espinho), um quarto de século de investigação - resultados e questões em aberto

Jorge Fernando Salvador / António Manuel S. P. Silva

1111 O Castro de Salreu (Estarreja), um povoado proto-histórico no litoral do Entre Douro e Vouga

Sara Almeida e Silva / António Manuel S. P. Silva / Paulo A. P. Lemos / Edite Martins de Sá

1127 Castro de Nossa Senhora das Necessidades (Sernancelhe): uma primeira análise artefactual Telma Susana O. Ribeiro

${ }_{1141}$ A cividade de Bagunte. O estado atual da investigação Pedro Brochado de Almeida

1153 Zoomorfos na cerâmica da Idade do Ferro no NW Peninsular: inventário, cronologias e significado Nuno Oliveira / Cristina Seoane

1163 Vasos gregos em Portugal: diferentes maneiras de contar a história do intercâmbio cultural na Idade do Ferro

Daniela Ferreira

1175 Os exotica da necrópole da Idade do Ferro do Olival do Senhor dos Mártires (Alcácer do Sal) no seu contexto regional

Francisco B. Gomes

\section{Antiguidade Clássica e Tardia}

1191 O uso de madeira como combustível no sítio da Quinta de Crestelos (Baixo Sabor): da Idade do Ferro à Romanização Filipe Vaz / João Tereso / Sérgio Simões Pereira / José Sastre / Javier Larrazabal Galarza / Susana Cosme / José António Pereira / Israel Espi

1207 Cultivos de Época Romana no Baixo Sabor: continuidade em tempos de mudança? João Pedro Tereso / Sérgio Simões Pereira / Filipe Santos / Luís Seabra / Filipe Vaz

1221 A casa romana na Hispânia: aplicação dos modelos itálicos nas províncias ibéricas Fernanda Magalhães / Diego Machado / Manuela Martins

1235 As pinturas murais romanas da Rua General Sousa Machado, n. ${ }^{5}$ 1, Chaves José Carvalho

1243 Trás do Castelo (Vale de Mir, Pegarinhos, Alijó) - Uma exploração agrícola romana do Douro

Tony Silvino / Pedro Pereira

1255 A sequência de ocupação no quadrante sudeste de Bracara Augusta: as transformações de uma unidade doméstica Lara Fernandes / Manuela Martins

1263 Os Mosaicos com decoração geométrica e geométrico-vegetalista dos sítios arqueológicos da área do Conuentus Bracaraugustanus. Novas abordagens quanto à conservação, restauro, decoração e datação Maria de Fátima Abraços / Licínia Wrench

1277 “Casa Romana” do Castro de São Domingos (Cristelos, Lousada): Escavação, Estudo e Musealização Paulo André de P. Lemos

1291 A arqueobotânica no Castro de Guifões (Matosinhos, Noroeste de Portugal): O primeiro estudo carpológico

Luís Seabra / Andreia Arezes / Catarina Magalhães / José Varela / João Pedro Tereso 
1305 Um Horreum Augustano na Foz do Douro (Monte do Castelo de Gaia, Vila Nova de Gaia) Rui Ramos

1311 Ponderais romanos na Lusitânia: padrões, formas, materiais e contextos de utilização Diego Barrios Rodríguez

1323 Um almofariz centro-itálico na foz do Mondego

Marco Penajoia

1335 Estruturas romanas de Carnide - Lisboa Luísa Batalha / Mário Monteiro / Guilherme Cardoso

1347 O contexto funerário do sector da "necrópole NO" da Rua das Portas de S. Antão (Lisboa): o espaço, os artefactos, os indivíduos e a sua interconectividade na interpretação do passado Sílvia Loja, José Carlos Quaresma, Nelson Cabaço, Marina Lourenço, Sílvia Casimiro, Rodrigo Banha da Silva, Francisca Alves-Cardoso

${ }_{1361}$ Povoamento em época Romana na Amadora - resultados de um projeto pluridisciplinar Gisela Encarnação / Vanessa Dias

1371 A Arquitectura Residencial em Mirobriga (Santiago do Cacém): contributo a partir de um estudo de caso Filipe Sousa / Catarina Felício

${ }_{1385}$ O fim do ciclo. Saneamento e gestão de resíduos nos edifícios termais de Mirobriga (Santiago do Cacém)

Catarina Felício / Filipe Sousa

1399 Balsa, Topografia e Urbanismo de uma Cidade Portuária Vítor Silva Dias / João Pedro Bernardes / Celso Candeias / Cristina Tété Garcia

1413 No Largo das Mouras Velhas em Faro (2017): novas evidências da necrópole norte de Ossonoba e da sua ocupação medieval Ricardo Costeira da Silva / Paulo Botelho / Fernando Santos / Liliana Nunes

1429 Instrumentos de pesca recuperados numa fábrica de salga em Ossonoba (Faro) Inês Rasteiro / Ricardo Costeira da Silva / Paulo Botelho

1439 A Necrópole Romana do Eirô, Duas Igrejas (Penafiel): intervenção arqueológica de 2016 Laura Sousa / Teresa Soeiro

1457 Ritual, descarte ou afetividade? A presença de Canis lupus familiaris na Necrópole Noroeste de Olisipo (Lisboa)

Beatriz Calapez Santos / Sofia Simões Pereira / Rodrigo Banha da Silva / Sílvia Casimiro / Cleia Detry / Francisca Alves Cardoso

1467 Dinâmicas económicas em Bracara na Antiguidade Tardia Diego Machado / Manuela Martins / Fernanda Magalhães / Natália Botica

1479 Cerâmicas e Vidros da Antiguidade Tardia do Edifício sob a Igreja do Bom Jesus (Vila Nova de Gaia) Joaquim Filipe Ramos

1493 Novos contributos para a topografia histórica de Mértola no período romano e na Antiguidade Tardia Virgílio Lopes

\section{8. Época Medieval}

1511 Cerâmicas islâmicas no Garb setentrional "português": algumas evidências e incógnitas Constança dos Santos / Helena Catarino / Susana Gómez / Maria José Gonçalves / Isabel Inácio / Gonçalo Lopes / Jacinta Bugalhão / Sandra Cavaco / Jaquelina Covaneiro / Isabel Cristina Fernandes / Ana Sofia Gomes 
1525 Contributo para o conhecimento da cosmética islâmica, em Silves, durante a Idade Média Rosa Varela Gomes

1537 Yábura e o seu território - uma análise histórico-arqueológica de Évora entre os séculos VIII-XII José Rui Santos

1547 A encosta sul do Castelo de Palmela - resultados preliminares da escavação arqueológica Luís Filipe Pereira / Michelle Teixeira Santos

1559 A igreja de São Lourenço (Mouraria, Lisboa): um conjunto de silos e de cerâmica medieval islâmica

Andreia Filipa Moreira Rodrigues

1571 O registo material de movimentações populacionais no Médio Tejo, durante os séculos XII-XIII. Dois casos de "sunken featured buildings", nos concelhos de Cartaxo e Torres Novas Marco Liberato / Helena Santos / Nuno Santos

1585 O nordeste transmontano nos alvores da Idade média. Notas para reflexão Ana Maria da Costa Oliveira

1601 Sepulturas escavadas na rocha do Norte de Portugal e do Vale do Douro: primeiros resultados do Projecto SER-NPVD

Mário Jorge Barroca / César Guedes / Andreia Arezes / Ana Maria Oliveira

1619 "Portucalem Castrum Novum" entre o Mediterrâneo e o Atlântico: o estudo dos materiais cerâmicos alto-medievais do arqueossítio da rua de D. Hugo, nํ. 5 (Porto) João Luís Veloso

1627 A Alta Idade Média na fronteira de Lafões: notas preliminares sobre a Arqueologia no Concelho de Vouzela

Manuel Luís Real / Catarina Tente

1641 Um conjunto cerâmico medieval fora de portas: um breve testemunho aveirense Susana Temudo

${ }_{1651}$ Os Lóios do Porto: uma perspetiva integrada no panorama funerário da Baixa Idade Média à Época Moderna em meios urbanos em Portugal

Ana Lema Seabra

1659 O Caminho Português Interior de Santiago como eixo viário na Idade Média Pedro Azevedo

1665 Morfologia Urbana: Um exercício em torno do Castelo de Ourém André Donas-Botto / Jaqueline Pereira

1677 Intervenção arqueológica na Rua Marquês de Pombal/Largo do Espírito Santo (Bucelas, Loures)

Florbela Estêvão / Nathalie Antunes-Ferreira / Dário Ramos Neves / Inês Lisboa

1691 O Cemitério Medieval do Poço do Borratém e a espacialidade funerária na cidade de Lisboa Inês Belém / Vanessa Filipe / Vasco Noronha Vieira / Sónia Ferro / Rodrigo Banha da Silva

1705 Um Espaço Funerário Conventual do séc. XV em Lisboa: o caso do Convento de São Domingos da Cidade Sérgio Pedroso / Sílvia Casimiro / Rodrigo Banha da Silva / Francisca Alves Cardoso

\section{9. Época Moderna e Contemporânea}

1721 Arqueologia Moderna em Portugal: algumas reflexões críticas em torno da quantificação de conjuntos cerâmicos e suas inferências históricas e antropológicas Rodrigo Banha da Silva / André Bargão / Sara da Cruz Ferreira

1733 Faianças de dois contextos entre os finais do século XVI e XVIII do Palácio dos Condes de Penafiel, Lisboa

Martim Lopes / Tomás Mesquita 
1747 Um perfil de consumo do século XVIII na foz do Tejo: O caso do Mercado da Ribeira, Lisboa Sara da Cruz Ferreira / Rodrigo Banha da Silva / André Bargão

1761 Os Cachimbos dos Séculos XVII e XVIII do Palácio Mesquitela e Convento dos Inglesinhos (Lisboa)

Inês Simão / Marina Pinto / João Pimenta / Sara da Cruz Ferreira / André Bargão / Rodrigo Banha da Silva

1775 "Tomar os fumos da erua que chamão em Portugal erua sancta». Estudo de Cachimbos provenientes da Rua do Terreiro do Trigo, Lisboa

Miguel Martins de Sousa / José Pedro Henriques / Vanessa Galiza Filipe

1787 Cachimbos de Barro Caulínitico da Sé da Cidade Velha (República de Cabo Verde)

Rodrigo Banha da Silva / João Pimenta / Clementino Amaro

1801 Algumas considerações sobre espólio não cerâmico recuperado no Largo de Jesus (Lisboa) Carlos Boavida

1815 Adereços de vidro, dos séculos XVI-XVIII, procedentes do antigo Convento de Santana de Lisboa (anéis, braceletes e contas)

Joana Gonçalves / Rosa Varela Gomes / Mário Varela Gomes

1837 Da ostentação, luxo e poder à simplicidade do uso quotidiano: arqueologia e simbologia de joias e adornos da Idade Moderna Portuguesa Jéssica Iglésias

1849 Os amuletos em Portugal - dos objetos às superstições: o coral vermelho Alexandra Vieira

1865 Cerâmicas de Vila Franca de Xira nos séculos XV e XVI Eva Pires

1879 «Não passa por teu o que me pertence». Marcas de individualização associadas a faianças do Convento de Nossa Senhora de Aracoeli, Alcácer do Sal Catarina Parreira / Íris Fragoso / Miguel Martins de Sousa

1891 Cerâmica de Leiria: alguns focos de produção

Jaqueline Pereira / André Donas-Botto

1901 Os Fornos na Rua da Biquinha, em Óbidos Hugo Silva / Filipe Oliveira

1909 A casa de Pêro Fernandes, contador dos contos de D. Manuel I: o sítio arqueológico da Silha do Alferes, Seixal (século XVI) Mariana Nunes Ferreira

1921 O Alto da Vigia (Sintra) e a vigilância e defesa da costa Alexandre Gonçalves / Sandra Santos

1937 O contexto da torre sineira da Igreja de Santa Maria de Loures Paulo Calaveira / Martim Lopes

1949 A Necrópole do Hospital Militar do Castelo de São Jorge e as práticas funerárias na Lisboa de Época Moderna Susana Henriques / Liliana Matias de Carvalho / Ana Amarante / Sofia N. Wasterlain

1963 SAND - Sarilhos Grandes Entre dois Mundos: o adro da Igreja e a Paleobiologia dos ossos humanos recuperados

Paula Alves Pereira / Roger Lee Jesus / Bruno M. Magalhães

1975 Expansão urbana da vila de Cascais no século XVII e XVIII: a intervenção arqueológica na Rua da Vitória no 15 a 17

Tiago Pereira / Vanessa Filipe

1987 Novos dados para o conhecimento do Urbanismo de Faro em época Moderna Ana Rosa 
1995 Um exemplo de Arqueologia Urbana em Alcoutim: o Antigo Edifício dos CTT Marco Fernandes / Marta Dias / Alexandra Gradim / Virgílio Lopes / Susana Gómez Martínez

2007 Palácio dos Ferrazes (Rua das Flores/Rua da Vitória, Porto): a cocheira de Domingos Oliveira Maia

Francisco Raimundo

2021 As muitas vidas de um edifício urbano: História, Arqueologia e Antropologia no antigo Recreatório Paroquial de Penafiel Helena Bernardo / Jorge Sampaio / Marta Borges

2035 O convento de Nossa Senhora da Esperança de Ponta Delgada: o contributo da arqueologia para o conhecimento de um monumento identitário João Gonçalves Araújo / N’Zinga Oliveira

2047 Arqueologia na ilha do Corvo... em busca da capela de Nossa Senhora do Rosário Tânia Manuel Casimiro / José Luís Neto / Luís Borges / Pedro Parreira

2059 Perdidos à vista da Costa. Trabalhos arqueológicos subaquáticos na Barra do Tejo Jorge Freire / José Bettencourt / Augusto Salgado

2071 Arqueologia marítima em Cabo Verde: enquadramento e primeiros resultados do projecto CONCHA

José Bettencourt / Adilson Dias / Carlos Lima / Christelle Chouzenoux / Cristóvão Fonseca / Dúnia Pereira / Gonçalo Lopes / Inês Coelho / Jaylson Monteiro / José Lima / Maria Eugénia Alves / Patrícia Carvalho / Tiago Silva

2085 Trabalhos arqueológicos na Cidade Velha (Ribeira Grande de Santiago, Cabo Verde): reflexões sobre um projecto de investigação e divulgação patrimonial André Teixeira / Jaylson Monteiro / Mariana Mateus / Nireide Tavares / Cristovão Fonseca / Gonçalo C. Lopes / Joana Bento Torres / Dúnia Pereira / André Bargão / Aurélie Mayer / Bruno Zélie / Carlos Lima / Christelle Chouzenoux / Inês Henriques / Inês Pinto Coelho / José Lima / Patrícia Carvalho / Tiago Silva

2103 A antiga fortificação de Quelba / Khor Kalba (E.A.U.). Resultados de quatro campanhas de escavações, problemáticas e perspectivas futuras Rui Carita / Rosa Varela Gomes / Mário Varela Gomes / Kamyar Kamyad

2123 Colónias para homens novos: arqueologia da colonização agrária fascista no noroeste ibérico Xurxo Ayán Vila / José Mạ . Señorán Martín 


\title{
NO LARGO DAS MOURAS VELHAS \\ EM FARO (2017): NOVAS EVIDÊNCIAS DA NECROPOLE NORTE DE OSSONOBA E DA SUA OCUPAÇÃO MEDIEVAL
}

\author{
Ricardo Costeira da Silva ${ }^{1}$, Paulo Botelho ${ }^{2}$, Fernando Santos $^{3}$, Liliana Nunes ${ }^{4}$
}

\begin{abstract}
RESUMO
No decorrer da intervenção arqueológica de minimização de impacte do projecto de arranjo urbanístico do Largo das Mouras Velhas e ruas adjacentes em Faro (2017), foram identificadas novas sepulturas de inumação pertencentes à necrópole norte de Ossonoba. Apresenta-se o contexto estratigráfico, a tipologia e arquitectura das sepulturas e o respectivo mobiliário funerário recuperado, procurando-se integrar estes novos achados no panorama global dos espaços sepulcrais ossonobenses já conhecidos.

Nesta intervenção foram ainda identificados, pela primeira vez nesta zona noroeste da cidade, vestígios de época medieval islâmica. Este contexto testemunhado por uma simples fossa detrítica colmatada entre os séculos XII/XIII permite relançar a discussão acerca da estratégia de ocupação periurbana de Ocsonoba.

Palavras-chave: Ossonoba (Faro), Necrópole romana, Sepulturas, Mobiliário funerário.
\end{abstract}

\begin{abstract}
During the archeological intervention survey to mitigate the impact of Largo das Mouras Velhas and surrouding streets urban project in Faro (2017), a few new burial graves belonging to the northern necropolis of Ossonoba were identified. It is presented the stratigraphic context, the typology and architecture of the graves and the related funerary furniture retrieved, as it is sought to integrate these new findings in the overall picture of the Ossonoba's burial spaces already known.

In this intervention it was also identified, for the first time in this northwest part of the city, traces of Medieval Islamic times. This context, witnessed by a simple detritic pit sealed between the 12th and 13th centuries, allows us to relaunch the discussion about Ocsonoba's peri-urban occupation strategy.
\end{abstract}

Keywords: Ossonoba (Faro), Roman necropolis, Graves, Funerary furniture.

\section{ENQUADRAMENTO - A NECRÓPOLE NORTE DE OSSONOBA}

Passados mais de 140 anos da primeira referência à necrópole norte de Ossonoba continuam, episodicamente, a surgir novos vestígios do principal espaço funerário daquela cidade portuária do sul da Lusitânia romana. Os resultados agora apresentados não são tão exuberantes face aos que Estácio da Vei- ga outrora pôs a descoberto (Santos, 1971: 188-192), ou mesmo a outros que se sucederam. Insistimos, porém, na divulgação dos resultados deste tipo de intervenções de natureza preventiva. Não pela eloquência dos resultados, mas pela importância de manter actualizado o atlas do subsolo de determinada cidade. Muito embora reproduzindo aspectos já atestados no perfil desta necrópole pública, os novos testemunhos proporcionam uma, sempre opor-

\footnotetext{
1. Faculdade de Letras da Universidade de Coimbra; rcosteiradasilva@gmail.com

2. Engobe - Arqueologia e Património Lda.; paulo.botelho@engobe.pt

3. Engobe - Arqueologia e Património Lda.; fernando.santos@engobe.pt

4. Engobe - Arqueologia e Património Lda.; liliana.nunes@engobe.pt
} 
tuna, actualização da base documental referente à paisagem funerária de Ossonoba.

Inscrita no espaço suburbano setentrional da cidade, esta necrópole dispunha-se em torno das duas principais vias que partiam para Norte, em direcção a Pax Iulia, e para Noroeste, em direcção a Balsa. Abarcando o espaço compreendido entre o actual Largo das Mouras Velhas, Rua João de Castro, Largo 25 de Abril, Rua Dr. João Lúcio e Rua das Alcaçarias (Bernardes, 2005: 30; Teichner \& alii., 2007: 161, fig. 1), ocuparia uma extensão aproximada de cerca de 4 hectares (Pereira, 2014: 295).

A identificação desta necrópole e respectiva "exploração" em 1878 por Estácio da Veiga, na qual começa por registar 38 sepulturas entre o Largo das Mouras Velhas e ao longo da fachada principal do Teatro Lethes (Santos, 1971: 188-192) marca, simultaneamente, o início da praxis arqueológica no meio urbano de Faro. Ao longo dos anos, este espaço cemiterial continua a agregar o fervor da acção arqueológica na cidade, sendo alvo de intervenções pontuais por diversos investigadores, incluindo alguns de igual nomeada, como Abel Viana (1951) ou Teresa Gamito (1992). Já na presente centúria, toda esta área tem sido alvo de sistemáticas intervenções arqueológicas avulsas de salvaguarda, no âmbito de obras públicas e privadas, como é o caso dos resultados agora apresentados. Entre estas destaca-se a escavação realizada em 2004 no Largo 25 de Abril (só em parte publicada), pelo elevado número de sepulcros detectado, por atestar a coexistência dos ritos de incineração e inumação, revelar novas tipologias funerárias e permitir estimar uma longa cronologia de ocupação/ utilização entre o séc. I e o séc. IV/VI d.C. (Teichner \& alii, 2007: 169). Dispensa-se, no entanto, elencar e aprofundar os detalhes de todas estas intervenções e enquadrá-las no contexto arqueológico de Faro uma vez que esse compêndio já se encontra realizado (Viegas, 2011: 79-98) somando-se, inclusivamente, várias sínteses referentes aos contextos funerários conhecidos de Ossonoba (eg. Bernardes, 2005; Teichner \& aii., 2007; Pereira, 2014: 277-295).

\section{NO LARGO DAS MOURAS VELHAS EM 2017}

A intervenção arqueológica que aqui se apresenta decorreu no âmbito da implementação de medidas de minimização referentes ao Projecto do Arranjo Urbanístico do Largo das Mouras Velhas e das ruas ad- jacentes, promovido pelo Município de Faro em 2017 e dirigida por dois dos autores deste texto (PB e FS). Neste contexto, previa-se a abertura de valas para instalação de diversas redes de infra-estruturas. No total, realizaram-se 43 valas, algumas atingindo os $2,30 \mathrm{~m}$ de profundidade. No curso dos trabalhos de acompanhamento arqueológico foram identificadas cinco ocorrências de interesse arqueológico situadas em torno do Largo das Mouras Velhas. Estas correspondem, essencialmente, a vestígios da necrópole norte de Ossonoba, ampliando-se o número total de sepulturas confirmadas e que aqui ultrapassava já a centena e meia de exemplares (Pereira, 2014: 293). Pela primeira vez, foi também aqui identificado um nível de ocupação de época medieval islâmica que conjuntamente se dá à estampa.

\subsection{Vestígios da Necrópole Norte de Ossonoba}

As ocorrências relacionadas com a necrópole romana surgiram junto ao limite sul do Largo das Mouras Velhas. No decurso da abertura de uma vala foram identificadas e registadas sete novas estruturas funerárias (Figura 1, n.ำ 5) que correspondem a inumações primárias individuais, todas com orientação NO-SE (Figura 2 e 3). De acordo com as características observadas, distinguem-se três tipos de sepulturas (Figura 3 e 4 ) que pouco diferem das tipologias conhecidas nesta necrópole e que, basicamente, representam as formas mais comuns de inumação presentes na Hispânia romana (Teichner $\mathbb{E}^{\circ}$ alii, 2007: 163). O tipo mais reiterado é constituído por quatro exemplares (u.e. 512, 520, 524 e 528 - Figura 3 ) e reporta-nos para enterramentos em fossa simples com cobertura de tegulae formando um telhado de duas águas rematado por tegula vertical em cada topo. Corresponde ao tipo B de Estácio da Veiga (Santos, 1971: planta n.․26) ou subtipo 2c de Sánchez Ramos (2005: 172, fig. 2) já referido, para este local, como sendo o mais frequente (Santos, 1971: 189).

O espólio arqueológico associado é escasso ou mesmo nulo. Numa sepultura (u.e. 524) recolheu-se um fragmento de bordo e arranque de gargalo de peça em vidro transparente, azul gelo (Figura $5, \mathrm{n}$. . 1). Não resulta fácil classificar esta peça pois os bordos tubulares ocorrem numa grande diversidade de formas. Pelas características do bordo (virado para o exterior e dobrado sobre si) e tendo em conta o gargalo alto e cilíndrico, poderá corresponder a um unguentário de colo largo de tipo "candelabro", possivelmente do tipo Isings $82 \mathrm{~A} 2$ de cronologia ampla 
mas limitada entre os finais do séc. I e o séc. III d.C. (Isings, 1957: 97-98). Noutra sepultura (u.e. 539) exumou-se uma pequena taça com carena baixa em cerâmica comum de pasta alaranjada fina mas com algumas inclusões de médio calibre (Figura $5-$ n. ${ }^{\circ}$ ). Duas outras sepulturas (u.e. 531 e 540 - Figura 3) apresentam fossa simples com cobertura plana de tegulae. Correspondem ao tipo $2 \mathrm{~b}$ de Sánchez Ramos (2005: fig. 2), também já documentado nesta necrópole (Viana, 1951). Neste caso, apenas uma sepultura (u.e. 531) forneceu mobiliário funerário. Trata-se de uma lucerna de volutas que podemos incluir no tipo Loeschcke IV/Dressel 11 (Figura 5, n.- 3). Este tipo formal apresenta volutas salientes no bico redondo, corpo circular sem asa e secção troncocónica e orla estreita, plana e lisa. A transição para o disco faz-se por uma moldura que define duas caneluras concêntricas. O disco é côncavo, com orifício de alimentação ligeiramente descentrado e está decorado com auriga sobre biga voltada à direita. Os dois cavalos a galope puxam o carro (com roda de cinco raios). Colhe paralelo muito próximo com vários exemplares conhecidos, destacando-se, pela sua maior proximidade, a lucerna n. .295 proveniente do depósito votivo de Santa Bárbara em Castro Verde (Maia e Maia, 1997: 92). Apesar de nos depararmos com autores que atribuem a esta forma diferentes cronologias para o início de produção, é consensual que o auge da mesma terá ocorrido em meados do século I d.C., assim como parece seguro que o seu termo se fixe entre o final do mesmo século e inícios do seguinte. Bailey (1980), por exemplo, estabelece para a produção do tipo IV Loeschcke em Itália, um período que se prolonga desde o início do principado de Augusto ao primeiro terço do segundo século II d.C.

Finalmente, uma última sepultura (u.e. 516) em fossa simples encontrava-se estruturada e coberta por grandes fragmentos pertencentes a um dollium e restos de imbrex. O contentor de armazenamento reutilizado apresenta bordo reentrante em forma de rim, munido de duas asas verticais com canelura central, adivinhando-se o corpo de perfil ovóide (Figura 6 - n.․․ 2). A reutilização de material cerâmico como parte integrante na construção de uma sepultura parece também não ser novidade nesta necrópole (Teichner $\mathbb{Z}$ alii, 2007: 166).

Um dos aspectos mais intrigante e patente nas sepulturas enunciadas prende-se com a ausência de vestígios osteológicos associados aos respectivos sedimentos de enchimento. Para esta situação, certificada pela antropóloga responsável (Sónia Ferro) que acompanhou a intervenção, não se apresenta qualquer justificação plenamente satisfatória ${ }^{5}$. Este facto poderá estar relacionado com processos pós-deposicionais, aparentemente associados á lixiviação do material osteológico causado pela exposição a terrenos com elevado teor de metais ferrosos e em frequente contacto com água. Situações semelhantes foram reportadas noutros locais tais como a necrópole romana do Porto dos Cacos em Alcochete (Sabrosa, 1996: 287; Monteiro, 2012: 72), onde se verificou uma deficiente selagem das sepulturas (de semelhante tipologia) que condicionou a conservação das ossadas humanas. Apesar de esta fundamentação suscitar alguma perplexidade, uma vez que noutros pontos da necrópole não se constata esta situação, importa mencionar o facto de neste preciso ponto a vala se sobrepor a uma antiga linha de água, provável braço da ribeira das Lavadeiras. Fica, porém, a certeza de se estar perante estratos em deposição primária. O topo das sepulturas encontra-se cerca de 1,50m de profundidade em relação à cota do pavimento actual e o,40m abaixo de um primeiro estrato (u.e. 510), datado de época romana, que sela os níveis da necrópole. Nesta camada, que cobre as sepulturas, foram recuperados alguns fragmentos de tegulae, imbrices e bojos de ânforas. Destaca-se, contudo, no espaço limítrofe (Figura 1, n.ํㅜ 4) e na continuidade deste estrato (composto por sedimento silto-arenoso, medianamente compacto de tonalidade castanho acinzentado - u.e. 406) a recolha de uma ânfora de perfil quase completo, encontrada fracturada in situ (Figura 6, n.․ 1). Trata-se de uma produção lusitana, local/regional, do tipo Almagro ${ }_{51 C}$ que corresponde, durante o Baixo-império (séc. III-V), à ânfora melhor representada e que conheceu maior volume de produção na Lusitania (Viegas, 2011: 237), sendo mesmo o modelo mais frequente em Faro (idem: 239, tabela 27). O exemplar identificado apresenta corpo fusiforme com $63 \mathrm{~cm}$ de perfil conservado (poderia atingir os $67 / 68 \mathrm{~cm}$ de altura), bordo de secção arredondada de onde arranca asa em fita que assenta no ombro (Figura $6,{ }^{\circ} .^{\circ} 1$ ), encai-

\footnotetext{
5. Tanto mais que, noutro ponto mais a ocidente deste local (vala 2 - Fig. 1, n. ${ }^{\circ}$ 2) foi possível verificar, no corte da respectiva vala, a existência de membros inferiores preservados (u.e. 209) com a mesma orientação que as restantes sepulturas identificadas.
} 
xando perfeitamente nos modelos produzidos nos vários centros oleiros conhecidos na região algarvia como a Quinta do Lago (Loulé) (Arruda e Fabião, 1990: fig. 6o-61), Manta Rota (Viegas, 2006: 177196), S. Bartolomeu de Castro Marim (Vasconcellos, 1898: 329-336; Alves, Diogo e Reiner, 1990: fig. 56) e Martinhal (Sagres) (Silva, Soares e Correia, 1990: 225-246).

Salta assim em evidência que, nesta área sul do Largo, não existe ao nível do registo estratigráfico qualquer vestígio entre o período romano e as camadas datadas do final de época moderna/contemporânea que se sobrepõem, fazendo supor que, em fase recente, alguma acção terá truncado e criado um hiato na estratigrafia. Esse fenómeno não se estende a todo o Largo das Mouras Velhas. Como adiante se apresenta, noutros pontos (zona poente, vala 3) foi ainda possível recuperar informação de cronologias intermédias.

Regista-se, por fim, o reconhecimento de mais uma estrutura, possivelmente funerária, durante a execução da vala 2, localizada no limite Oeste do Largo das Mouras Velhas (Figura 1, n.ำ1). No perfil exposto observa-se apenas a presença de tegulae dispostas em cutelo (u.e. 207 - Figura 4 - A), aparentemente com uma orientação semelhante às anteriores (NO-SE). O desenvolvimento destes vestígios para lá do limite da área afectada impossibilitou que se pudesse aferir com maior rigor o seu desenho e natureza. Parece, no entanto, tratar-se de um sepulcro de tipo C da classificação de Estácio da Veiga (Santos, 1971: planta n. ${ }^{26}$ ) composto por uma caixa construída com tegulae colocadas ao alto e cobertas com o mesmo material disposto horizontalmente (tipo 3 a de Sánchez Ramos (2005: fig. 2). A comprovar-se, este será o vestígio material que, por agora, marca o limite ocidental desta necrópole.

\subsection{As evidências medievais no Largo das Mou- ras Velhas}

Uma das novidades desta intervenção foi a identificação, pela primeira vez nesta zona noroeste da cidade, de um contexto de época medieval islâmica. Este foi localizado no limite ocidental do Largo das Mouras Velhas (vala 3 - Figura 1 - n.. 3 ) e circunscreve-se a uma simples fossa detrítica de planta sub-circular escavada no substrato geológico (Figura 7), numa área onde este se encontra a uma cota mais elevada. Esta encontrava-se colmatada por dois estratos (u.e.s 308 e 309) de onde foi possível recolher um conjunto singelo mas relevante de louça doméstica medieval a par de fauna (malacológica e mamalógica), cerâmica de construção (telha de meia cana) e restos residuais de cerâmica romana (ânfora e fundo de taça em terra sigillata).

Para além da louça doméstica de superfícies foscas, reduzida maioritariamente a fragmentos informes, distingue-se a presença de cerâmica vidrada e dois candis. Estes contentores de fogo para iluminação, fabricados em pasta creme bem depurada, não apresentam qualquer decoração ou tratamento superficial. Não foi possível restituir nenhum perfil completo. Um encontra-se reservado ao depósito discóide carenado e ao colo alto (troncocónico invertido) com bordo simples ligeiramente extrovertido e lábio boleado (Figura 8, n.․․ 2). O outro, acrescenta ainda, uma asa de laço/vertical de secção em " $D$ " e o arranque do bico (Figura 8, n.ำ 1). Candis tipologicamente semelhantes são comuns nestes contextos islâmicos do sul peninsular a partir do reino de taifas, atingindo grande difusão no período almorávida - entre o séc. XI-XII (Catarino, 2017: 531).

Com o mesmo fabrico (pasta esbranquiçada e compacta), regista-se uma base com pé que poderá pertencer a um recipiente com três (trípode) ou quatro pequenos apoios (Figura 9, n.․ 6). Em termos morfológicos colhe o melhor paralelo na Alcáçova do Castelo de Mértola, assemelhando-se a pequeno alguidar proveniente de níveis datados do séc. XII (Torres, 1987: n.. 34 ).

Não obstante, neste contexto destacam-se quantitativamente as formas abertas que podemos associar aos serviços de mesa. De superfícies vidradas, surgem em peças com pastas de boa qualidade, claras e esbranquiçadas, devendo corresponder, muito provavelmente, a grandes tigelas ou malgas. Dois exemplares, um fundo e um bordo, apresentam superfície monocroma a verde e marcas de decoração impressa/estampilhada (Figura 9, n. ${ }^{\circ} 1$ e 2). Os restantes (11 fragmentos) ostentam superfícies meladas, maioritariamente ( 7 ) com motivos a óxido de manganés (Figura 9, n.ํㅜ 3-5). Estas peças encontram-se resumidas ao fundo, impossibilitando a obtenção de paralelos formais. Os dados disponíveis para o território Algarvio permitem, porém, afirmar que as peças vidradas (monocromas estampilhadas e com pintura a óxido de manganês) se disseminam durante a fase almorávida e almóada, predominando os vidrados melados (com ou sem motivos a manganés) sobre os de outra coloração (Gómez Martínez \& alii, 2015: 
42-44). Por outro lado, o facto destas peças apresentarem, como característica dominante, fundos espessos com pés anelares bem salientes (Figura 9, n. 1 1 e 3-5), poderá adscrevê-las ao período almóada (Catarino, 1997-98: 827). Por estes motivos, aponta-se para que a colmatação desta fossa possa ter ocorrido entre o séc. XII-XIII.

\section{SÍNTESE}

A necrópole romana Norte de Ossonoba tem vindo a ser documentada através de sucessivas intervenções arqueológicas preventivas e de salvaguarda numa área que se estende entre o Largo das Mouras Velhas até à rua D. João de Castro (Bernardes, 2005: 30). Além da sua extensão e circunscrição espacial, os contextos analisados permitem comprovar a sua ampla cronologia de utilização entre o séc. I/II e o séc. VI (Teichner $\&$ alii, 2007). Os dados agora expostos embora não forneçam, efectivamente, novidades de vulto, contribuem, modestamente, para actualizar os números e informação concernente a este espaço cemiterial. Na verdade, surgem num local já identificado com a necrópole (apesar de poderem marcar o limite máximo ocidental) e registam tipologias de enterramento já conhecidas em Ossonoba, nomeadamente a sepultura com telhado de duas águas formado por tegulae (tipo B de Estácio da Veiga). É igualmente escasso o mobiliário funerário recuperado. Não obstante, conta-se a presença de alguns objectos que participaram no processo de inumação e nos fornecem pistas de âmbito cronológico que se integram no período alto-imperial. Para além do fragmento em vidro do que parece tratar-se de um unguentário do tipo Isings $82 \mathrm{~A} 2$ (finais do séc. I - séc. III d.C.), destaca-se uma lucerna Loeschcke IV/Dressel 11 com cronologia mais refinada entre meados e finais do séc. I d.C. (Deneauve, 1969: 126), embora podendo estender-se aos inícios da centúria seguinte.

O dado mais original reside, como referido, na identificação, inédita na zona noroeste da cidade já afastada do núcleo primitivo que tem por base a Vila-a-Dentro, de um contexto de época medieval islâmica. Os testemunhos identificados circunscrevem-se a uma fossa detrítica colmatada entre os séculos XII/XIII e são insuficientes para que sobre eles se possam tecer considerações mais desenvolvidas sobre a natureza do sítio que integravam. Devem, no entanto, relançar a discussão sobre a es- tratégia de ocupação do espaço peri-urbano de Santa Maria de Ocsonoba. Os vestígios poderiam integrar uma estrutura habitacional nos arrabaldes da cidade, não sendo também de descartar a possibilidade do cemitério islâmico decalcar, até certo ponto, o espaço da necrópole romana.

Dentro do que são as virtualidades da arqueologia de salvaguarda em meio urbano, a actual intervenção vem contribuir para o adensar de questões que se enredam neste complexo e interessante desvendar das cidades sobrepostas. Neste processo de construção do mapa do subsolo urbano juntam-se, assim, mais alguns fragmentos. Uns apoiam a leitura de elementos já conhecidos embora de contornos ainda em aberto, outros apontam para problemáticas emergentes e por emergir.

\section{BIBLIOGRAFIA}

ALVES, Francisco; DIOGO, António Dias; REINER, Francisco (1990) - A propósito dos fornos de cerâmica lusitano-romanos de S. Bartolomeu do Mar. In ALARCÃO, Adília; MAYET, Françoise, eds. - Ânforas Lusitanas. Tipologia, produção, comércio (Actas das Jornadas de estudo. Conimbriga, 1988). Coimbra / Paris, pp. 193-198.

ARRUDA, Ana M.; FABIÃO, Carlos (1990) - Ânforas da Quinta do Lago (Loulé). In ALARCÃO, Adília; MAYET, Françoise, eds. - Ânforas Lusitanas. Tipologia, produção, comércio (Actas das Jornadas de estudo. Conimbriga, 1988). Coimbra / Paris, pp. 199-213.

BAILEY, Donald M. (1980) - A Catalogue of the Lamps in the British Museum, II. Roman Lamps made in Italy. Londres.

BERNARDES, João P. (2005) - As necrópoles de Ossonoba. Morrer em Faro há 2000 anos. Caminhos do Algarve Romano, Catálogo da Exposição. Faro, pp. 26-34.

CATARINO, Helena (1997-1998) - O Algarve Oriental durante a ocupação islâmica: povoamento rural e recintos fortificados. "Al’Ulyã”, n. 6, 3 vols., Loulé: Arquivo Histórico Municipal.

CATARINO, Helena (2017) - Fichas de catálogo. Núcleo VI. Época islâmica do Gharb ao Algarve: cinco séculos de Islão. Loulé, Territórios, Memórias, Identidades. Catálogo da Exposição. Museu Nacional de Arqueologia - Museu Municipal de Loulé, Imprensa Nacional, pp. 504-540; 542-570.

DENEAUVE, Jean (1969) - Lampes de Carthage. Paris: Centre de la Recherche Scientifique.

GAMITO, Teresa J. (1992) - Cemitério romano do século II/III - Faro, Rua das Alcaçarias. Conimbriga. 31, pp. 99-118.

GÓMEZ MARTÍNEZ, Susana; GONÇALVES, Maria J.; INÁCIO, Isabel ; SANTOS, Constança; COELHO, Catarina; LIBERATO, Marco; GOMES, Ana S.; BUGALHÃO, Jacin- 
ta; CATARINO, Helena; CAVACO, Sandra; COVANEIRO, Jaquelina; FERNANDES, Isabel C. (2015) - A cidade e o seu território no Gharb al-Andalus através da cerâmica. Actas $X$ Congresso Internacional a Cerâmica Medieval no Mediterrâneo / Proceedings of $10^{\text {th }}$ International Congress on Medieval Pottery in the Mediterranean. Silves: Câmara Municipal de Silves / Campo Arqueológico de Mértola. T. 1, pp. 19-50.

ISINGS, Clasina (1957) - Roman Glass from Dated Finds. Gröningen: D. B. Wolters.

MAIA, Maria; MAIA, Manuel (1997) - Lucernas de Santa Bárbara. Castro Verde: Cortiçol.

MONTEIRO, José L. (2012) - Necrópole Romana do Porto dos Cacos (Alcochete, Portugal). Dissertação de Mestrado em Arqueologia apresentada à Faculdade de Letras da Universidade de Lisboa.

PEREIRA, Carlos (2014) - As necrópoles romanas do Algarve: acerca dos espaços da morte no extremo sul da Lusitânia. Tese de doutoramento em História (Arqueologia) apresentada Faculdade de Letras da Universidade de Lisboa. Policopiado.

SABROSA, Armando (1996) - Necrópole Romana do Porto dos Cacos (Alcochete). In FILIPE, Graça; RAPOSO, Jorge, eds. - Ocupação Romana dos Estuários do Tejo e do Sado. Lisboa: Câmara Municipal do Seixal, pp. 283-30o.

SÁNCHEZ RAMOS, Isabel (2005) - Las necrópolis de Corduba durante la Antigüedad tardia. AnMurcia. Múrcia. 21, pp. 165-177.

SANTOS, Maria L. E. da V. A. dos (1971) - Arqueologia Romana do Algarve. Associação dos Arqueólogos Portugueses, 1. Lisboa.

SILVA, Carlos T.; SOARES, Antónia; CORREIA, Virgílio H. (1990)- "Produção de ânforas romanas no Martinhal (Sagres)”, In ALARCÃO, Adília; MAYET, Françoise, eds. Ânforas Lusitanas. Tipologia, produção, comércio (Actas das Jornadas de estudo. Conimbriga, 1988). Coimbra / Paris, pp. $225-246$.

TEICHNER, Felix; SCHIERL, Thomas; GONÇALVES, Ana; TAVARES, Paula (2007) - Sebastião Philipes Martins Estácio da Veiga e as necrópoles romanas de Ossonoba (Faro). Xelb. Silves. 7, pp. 159-178.

TORRES, Cláudio (1987) - Cerâmica Islâmica Portuguesa. Catálogo. Lisboa: Fundação Calouste Gulbenkian.

VASCONCELLOS, José L. (1898) - Olaria luso-romana em S. Bartolomeu de Castro Marim. O Arqueólogo Português, 4, pp. 329-336.

VIANA, A. (1951) - O cemitério luso-romano do Bairro Letes (Faro). Separata da revista, Brotéria, Lisboa. 53: 2/3, pp. 1-23.
VIEGAS, C. (2006) - O Forno romano da Manta Rota (Algarve). Setúbal Arqueológica (Simpósio Internacional Produção e Comércio de Preparados Piscícolas durante a Proto-História e a Época Romana no Ocidente da Península Ibérica, Homenagem a Françoise Mayet). 13, pp. 177-196.

VIEGAS, C. (2011) - A ocupação romana do Algarve: estudo do povoamento e economia do Algarve central e oriental no período romano. Universidade de Lisboa, Lisboa: UNIARQ. 

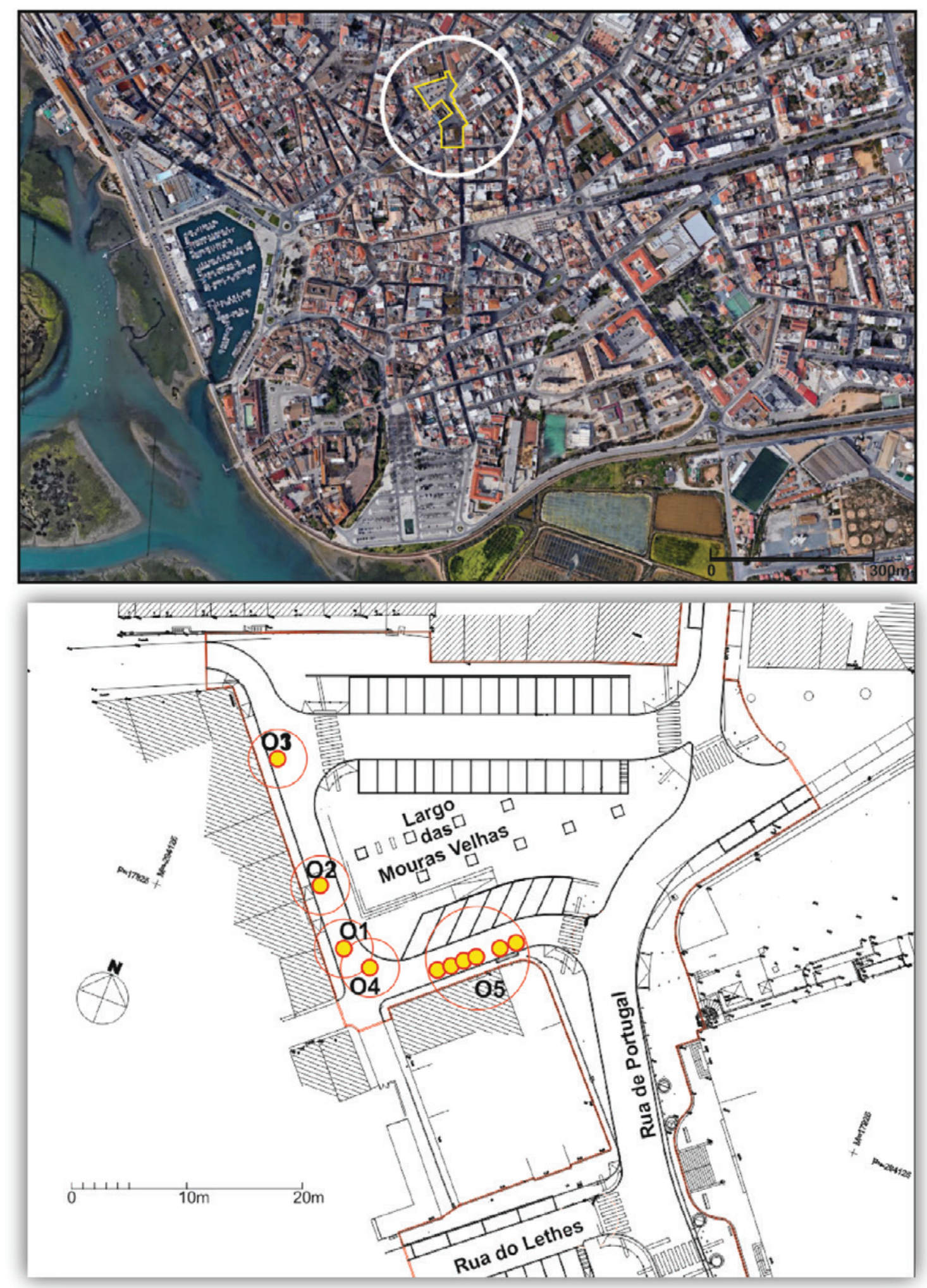

Figura 1-Em cima, localização da intervenção na malha urbana da actual cidade de Faro (base do Google Earth). Em baixo, localização das ocorrências arqueológicas na planta de pormenor do Largo das Mouras Velhas. 


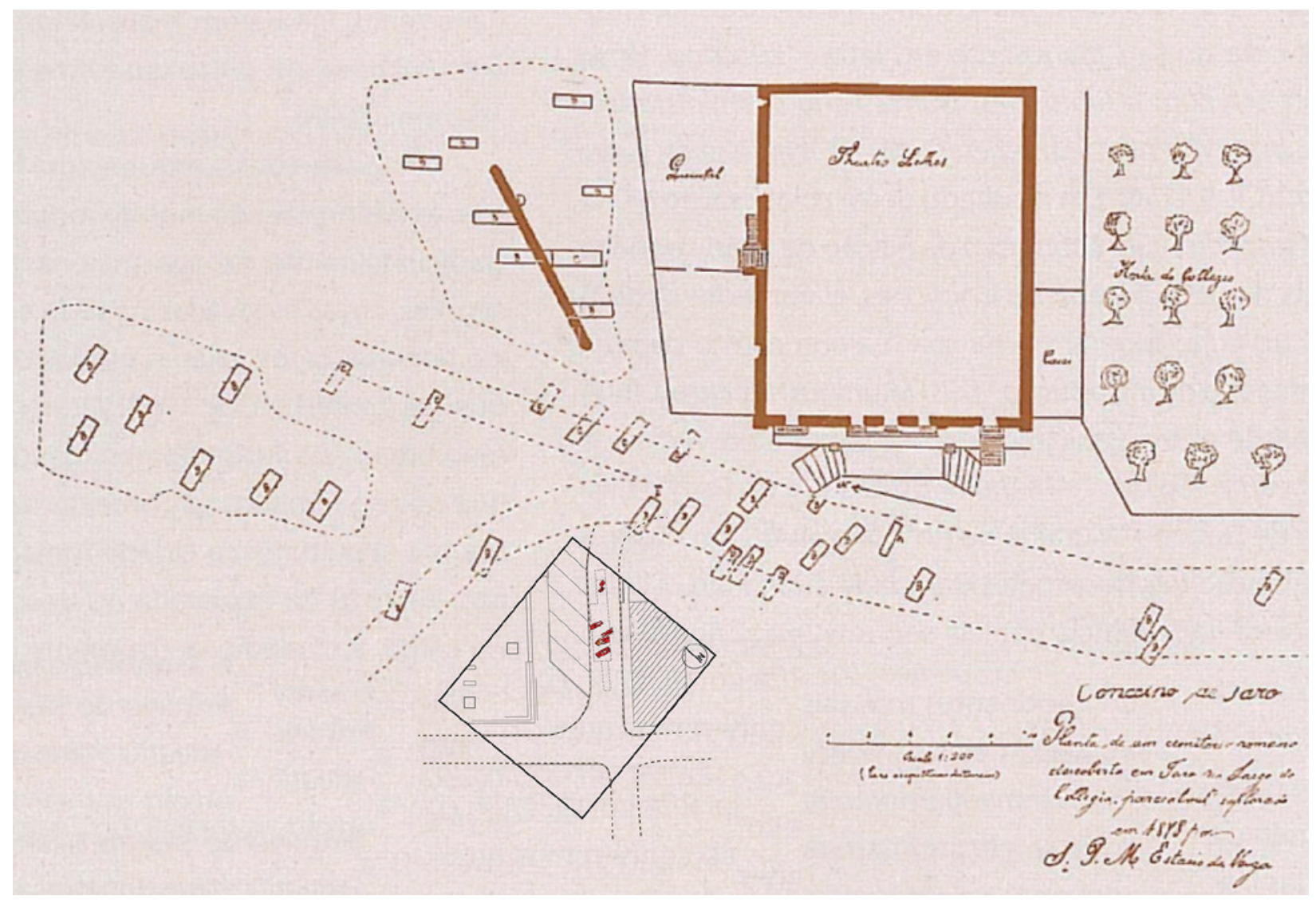

Figura 2 - Implantação das novas sepulturas na planta elaborada por Estácio da Veiga em 1878 (base retirada de Santos, 1971: planta n. ${ }^{2}$ ). 

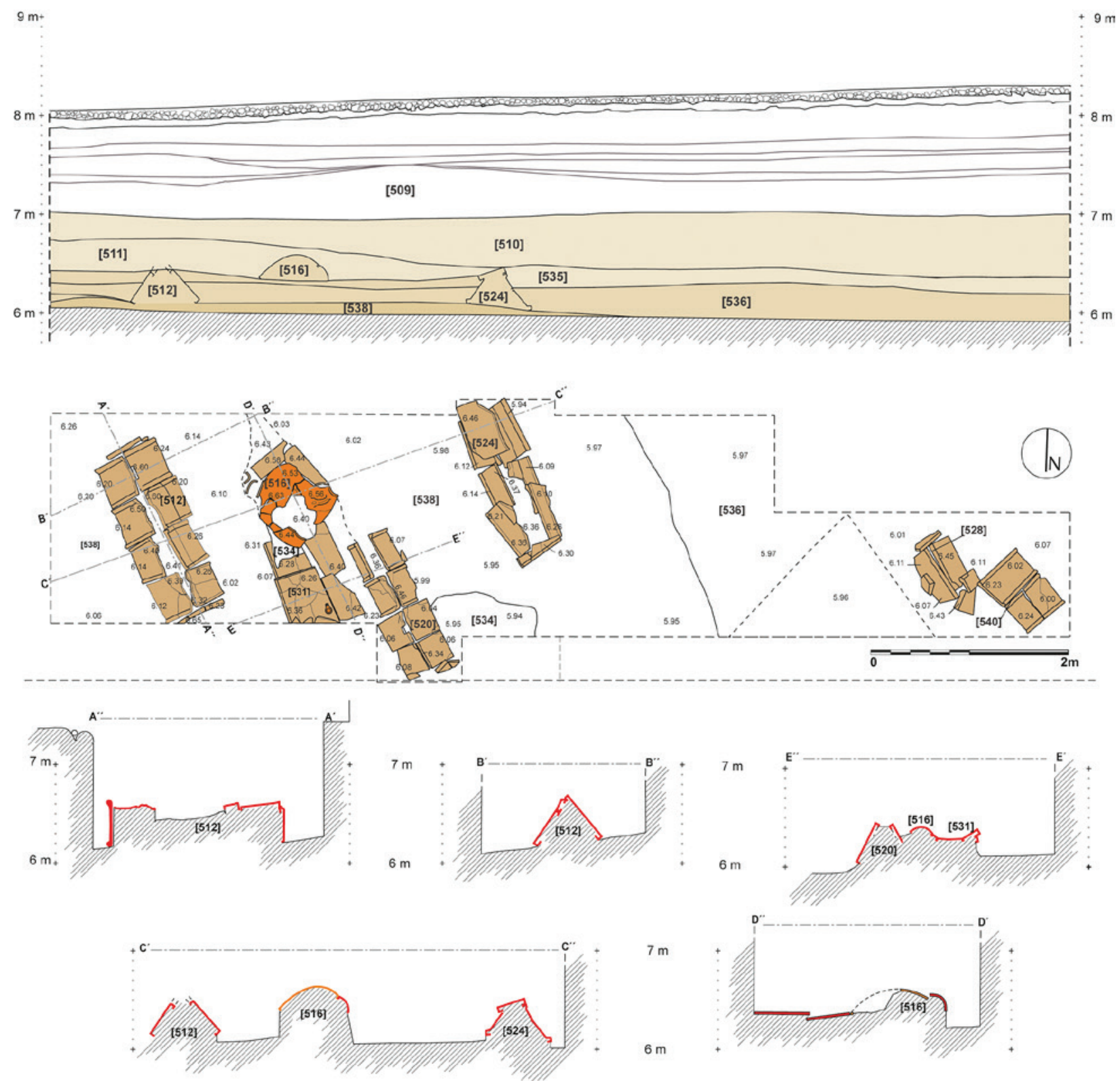

Figura 3 - Plano final e corte das sepulturas identificadas (ocorrência 5) e perfil da vala 5 

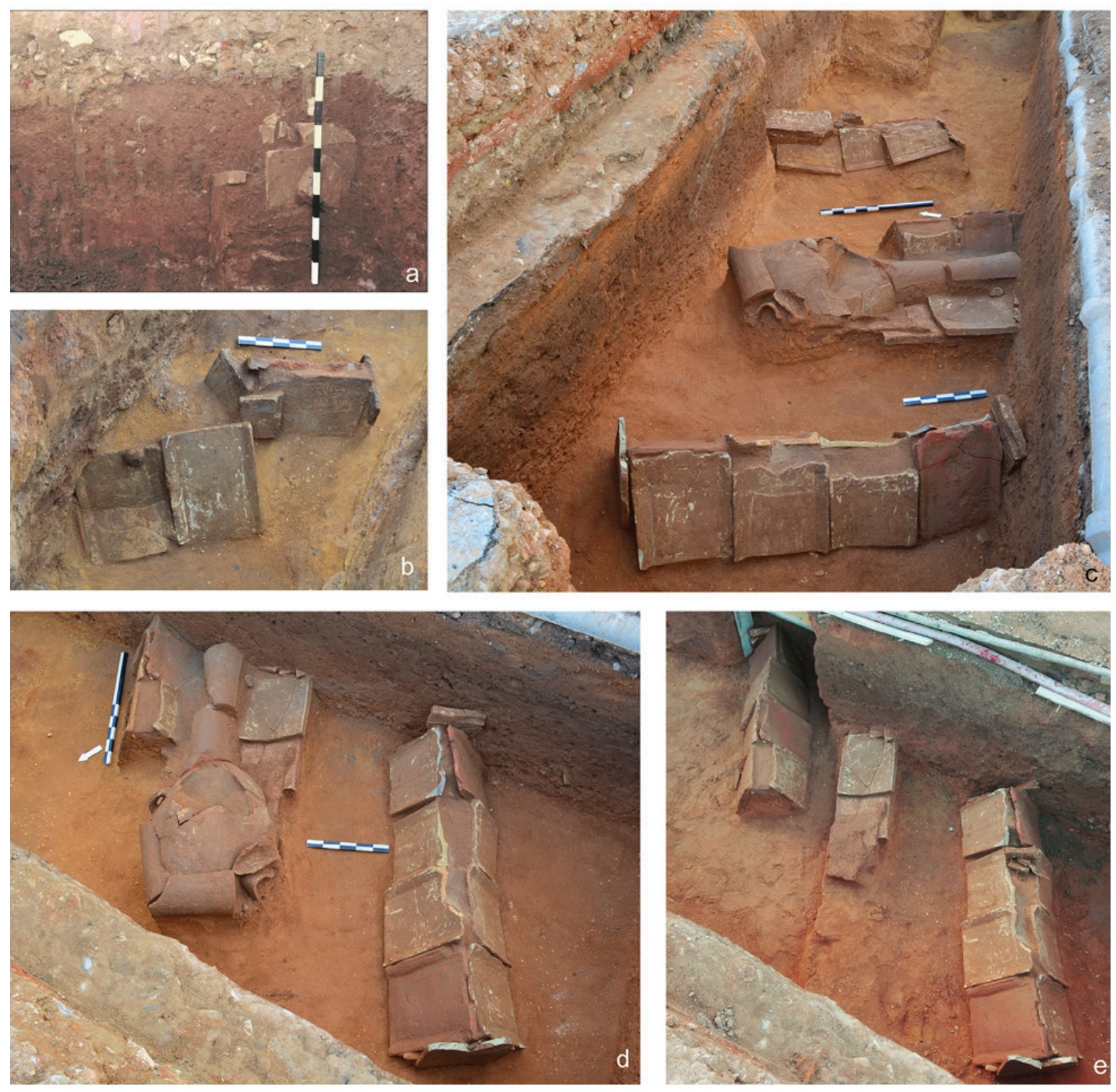

Figura 4 - Vista geral e de pormenor das várias sepulturas identificadas. 

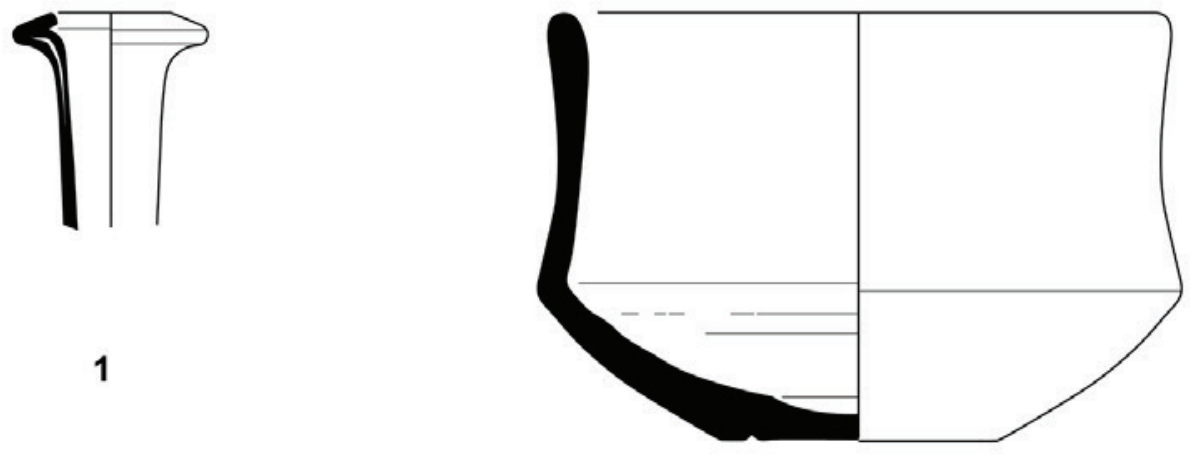

2
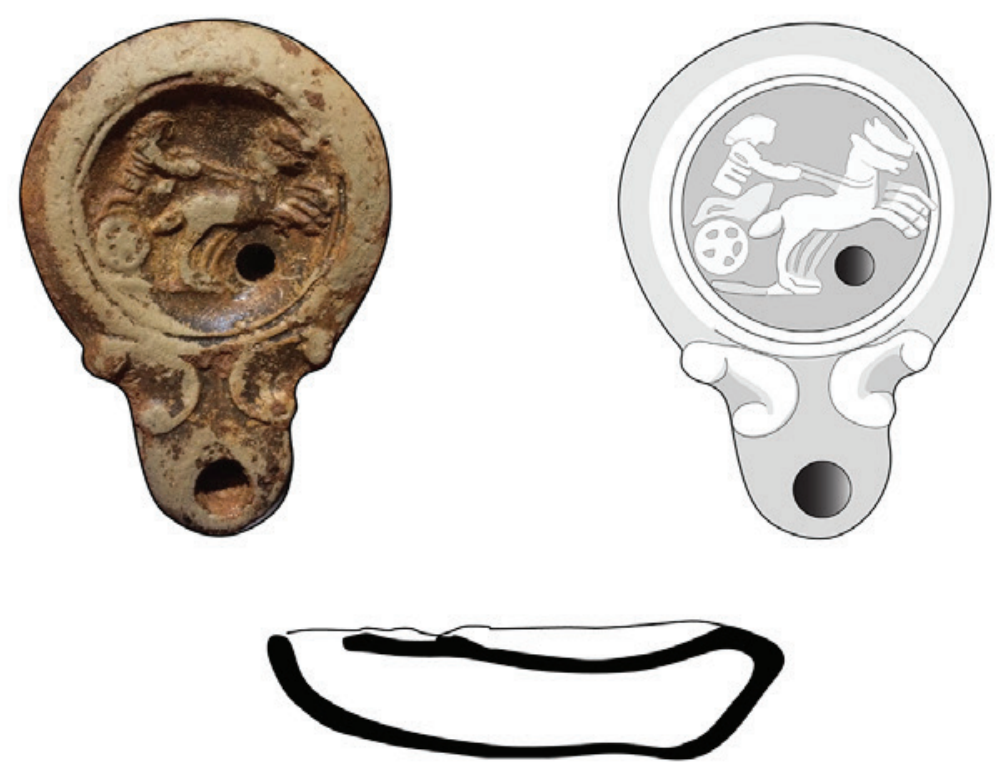

3

$5 \mathrm{~cm}$

Figura 5-Mobiliário funerário recuperado. 

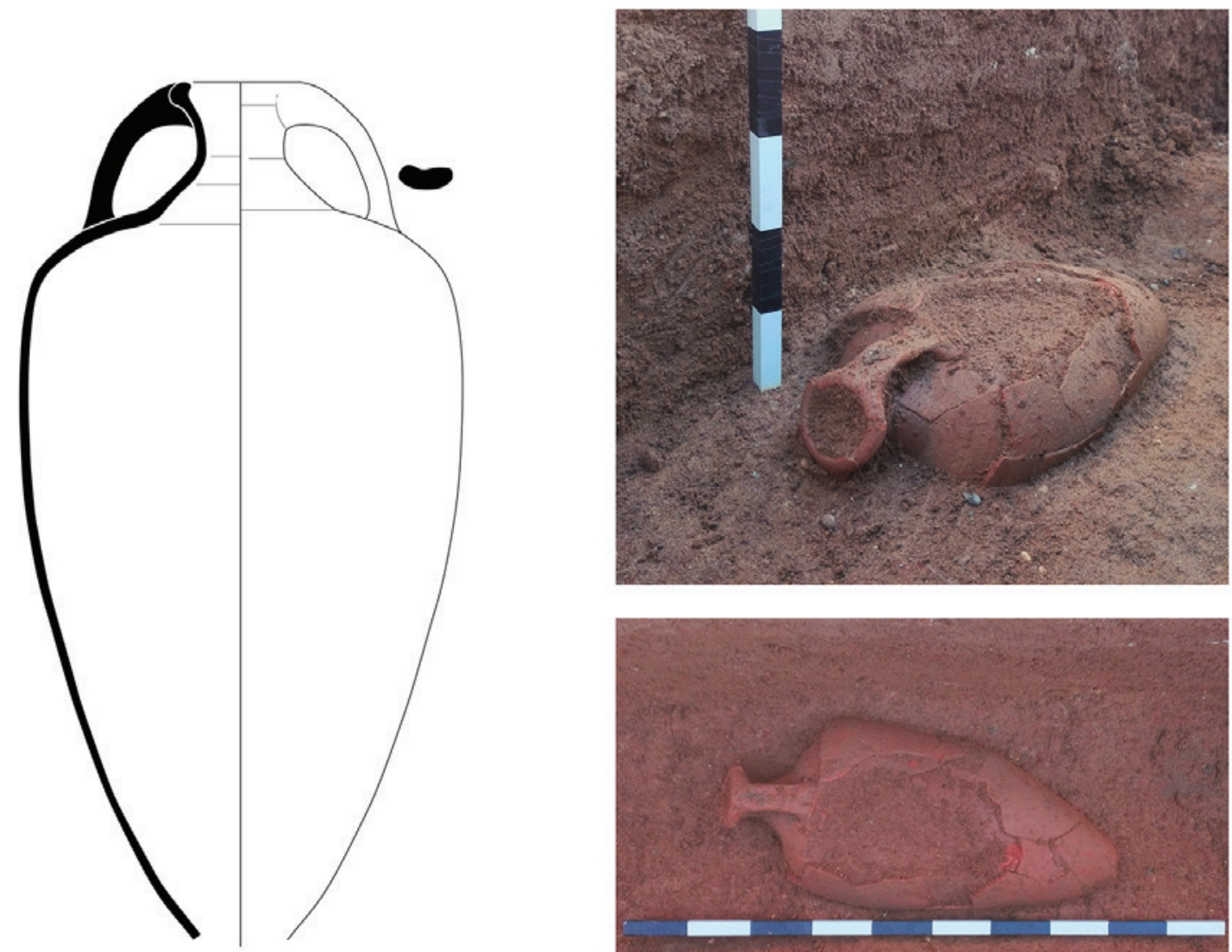

1

$15 \mathrm{~cm}$
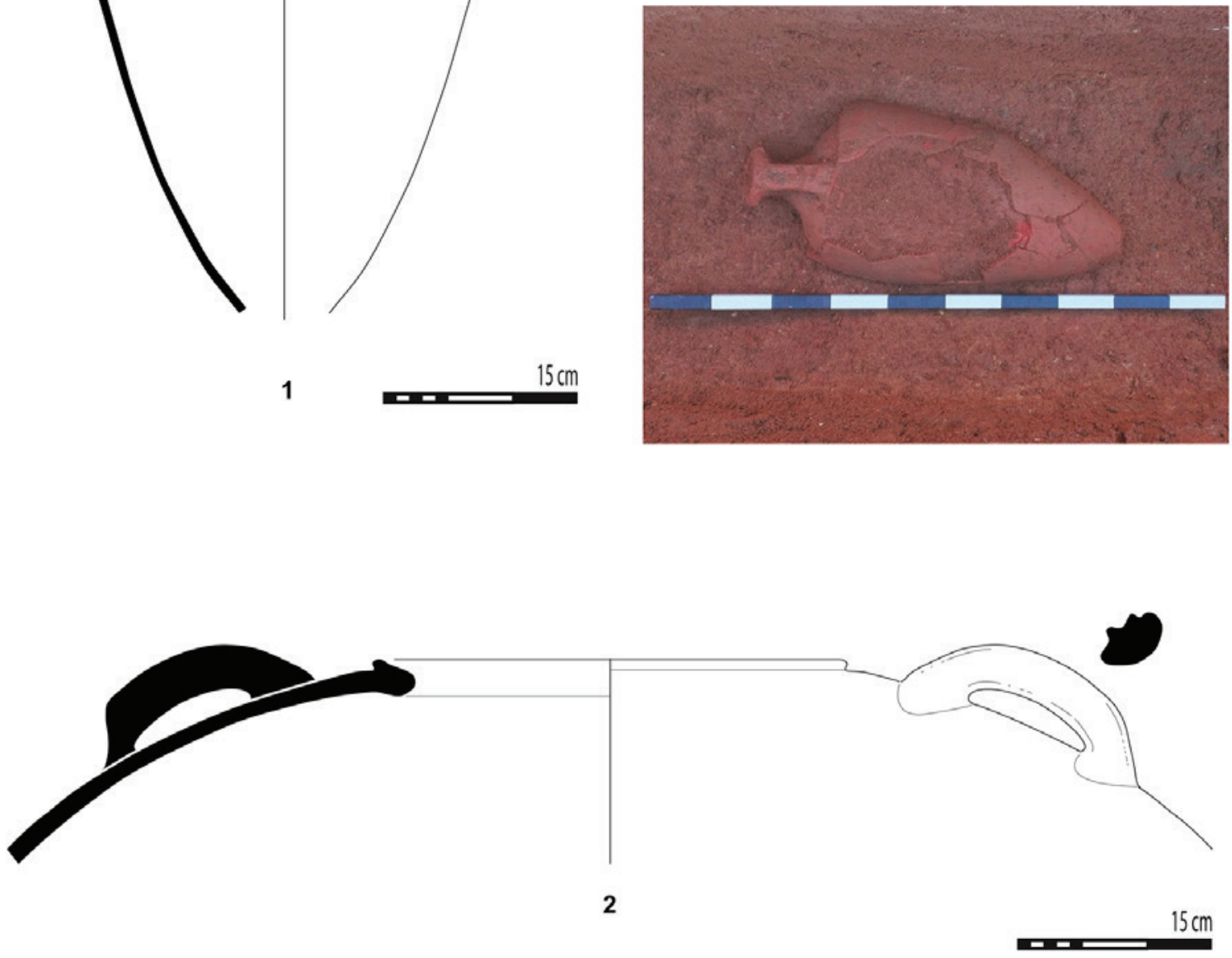

Figura 6 - Em cima, ânfora (ocorrência n.ํ4). Em baixo, dollium que compunha sepultura - u.e. 516. 

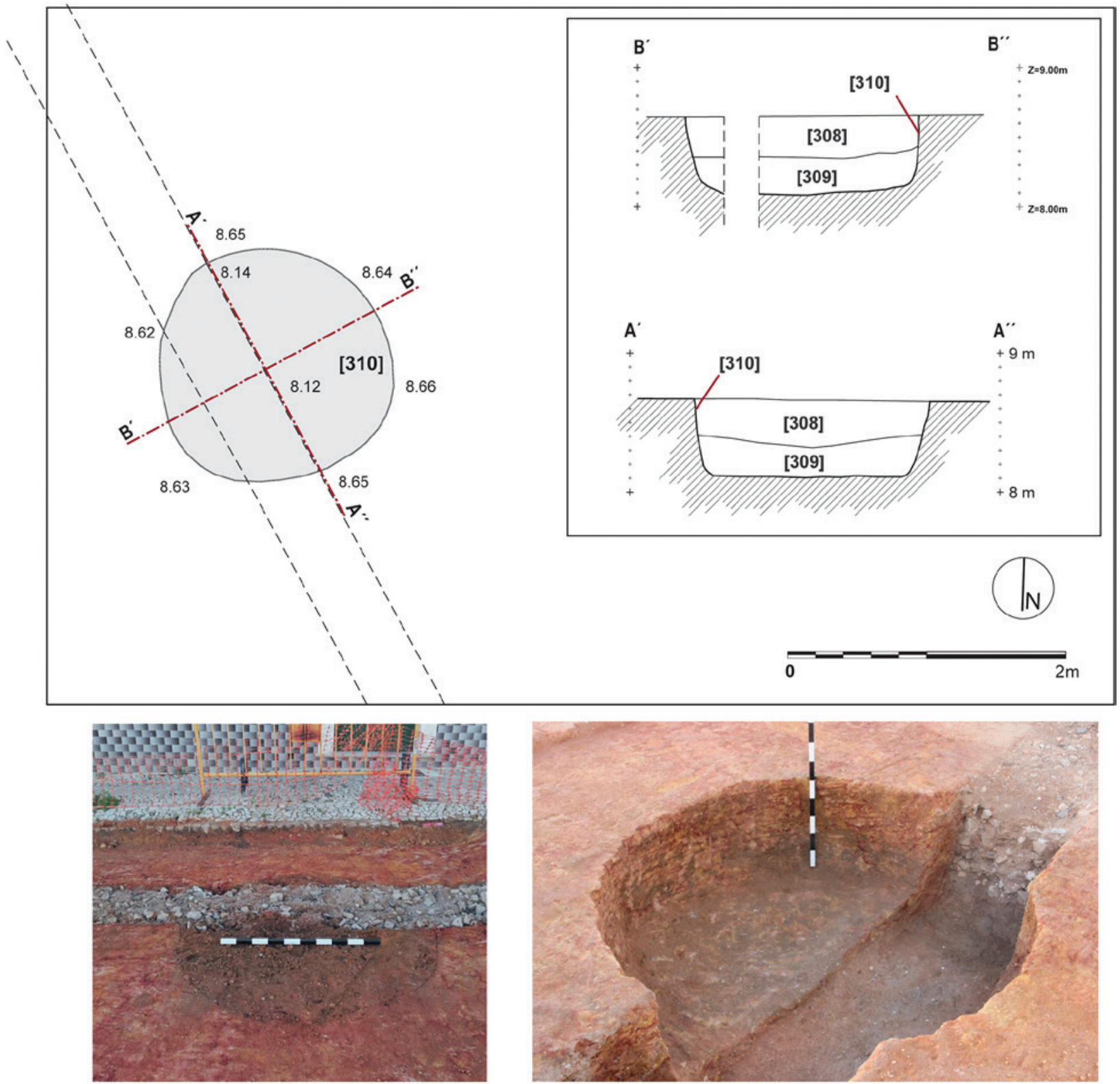

Figura 7 - Planta, perfil e vista geral de fossa medieval (vala 3). 

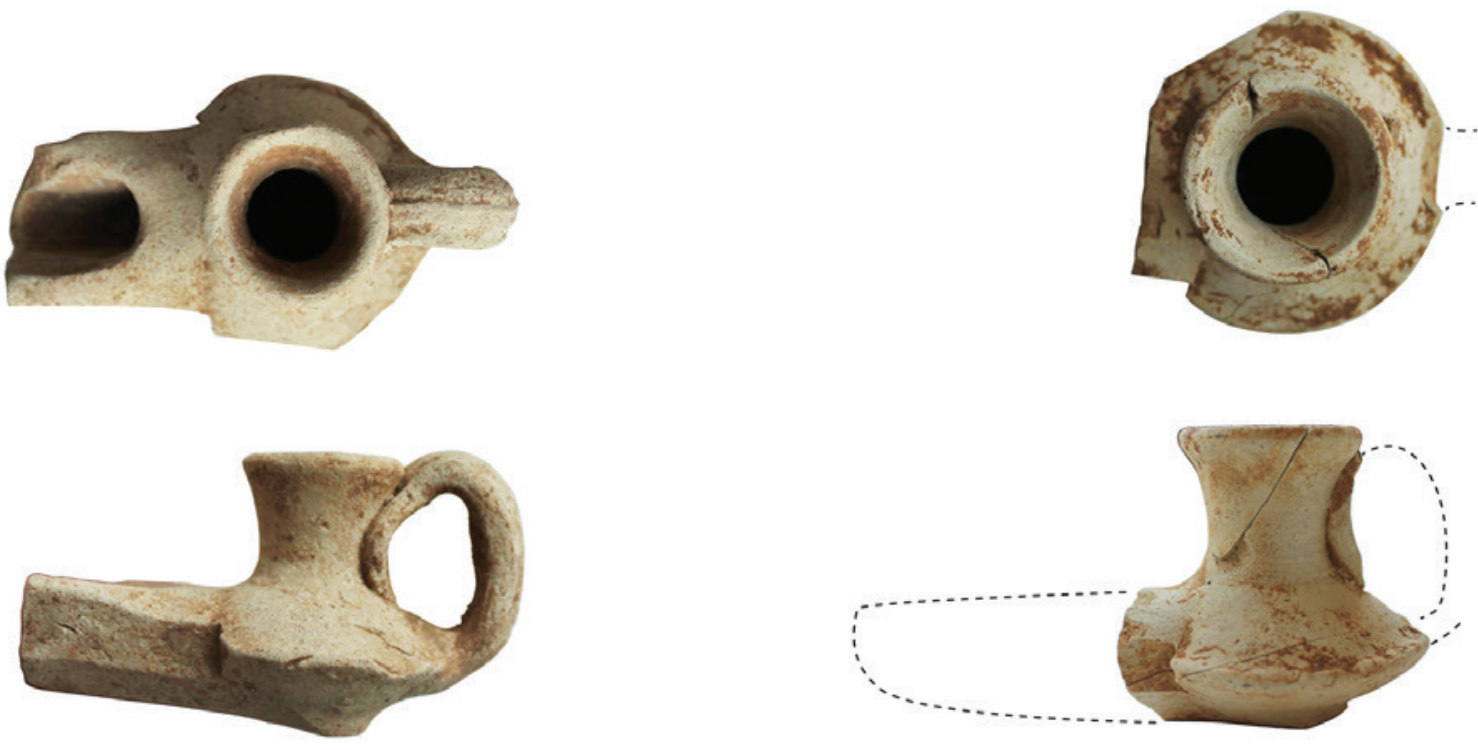

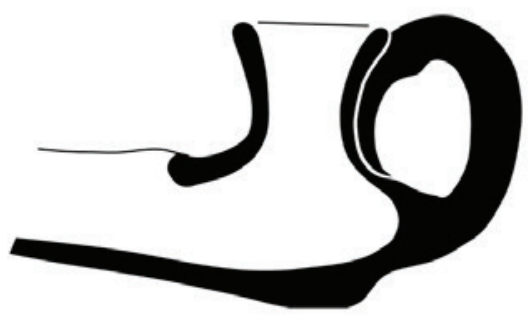

1

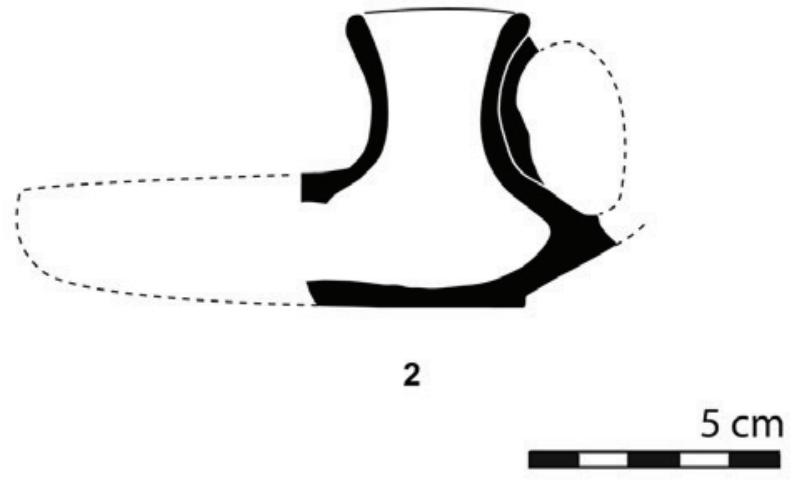

Figura 8-Candis. 

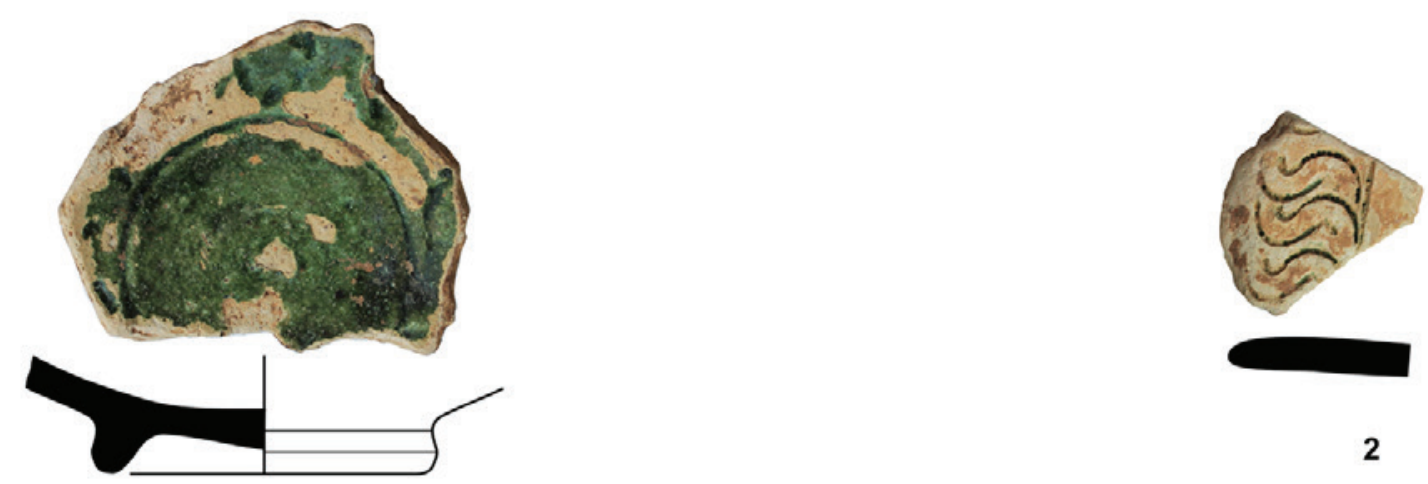

2

1
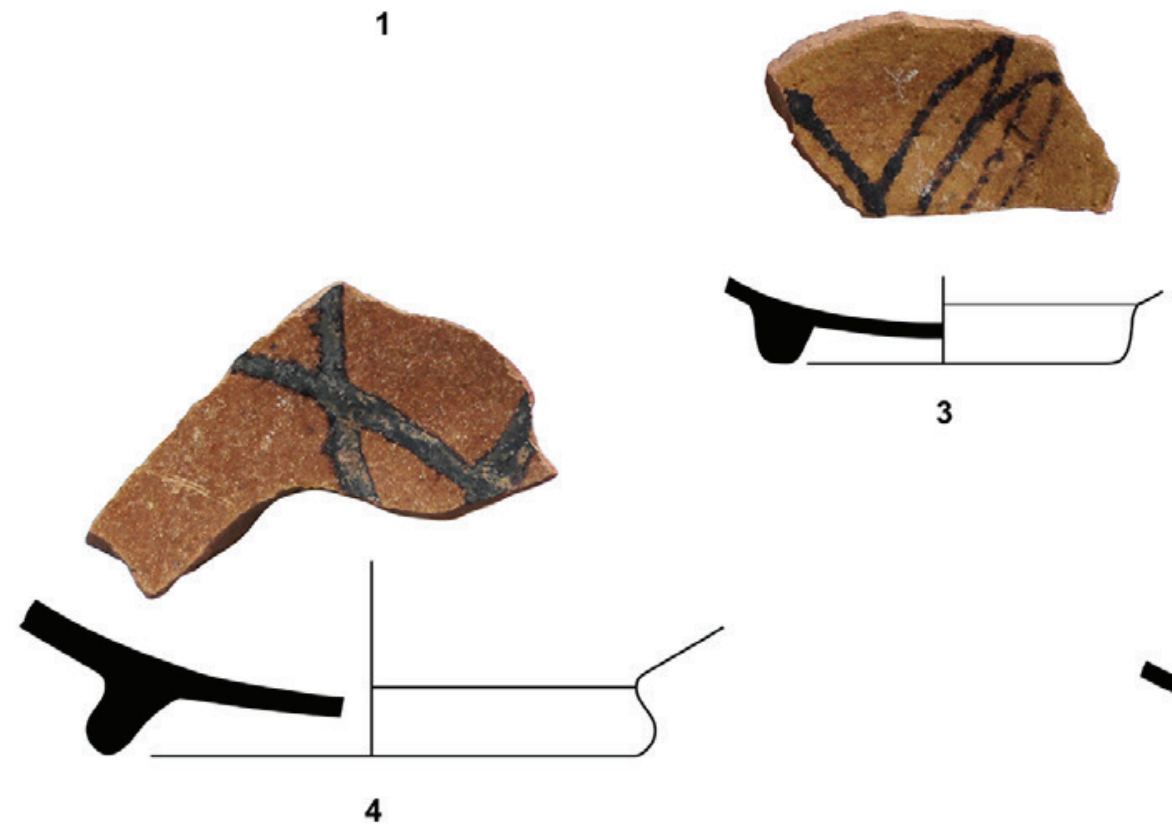

3
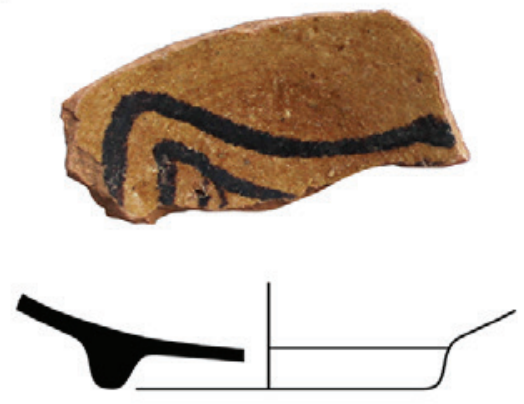

5
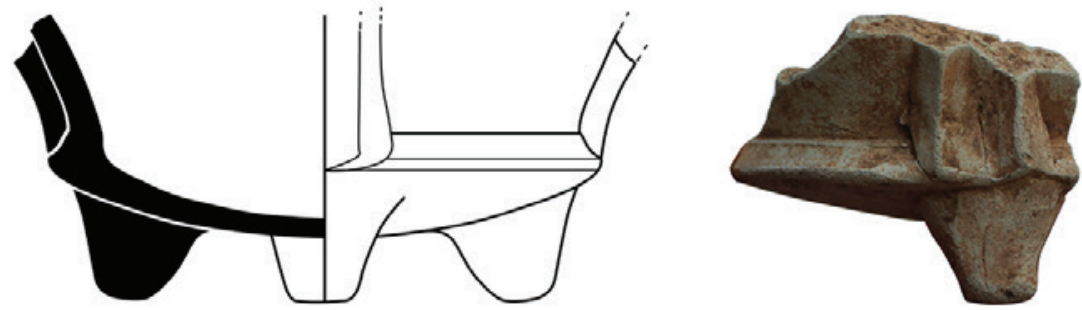

$5 \mathrm{~cm}$

6

Figura 9 - Conjunto cerâmico recuperado nos níveis de colmatação da fossa medieval. 


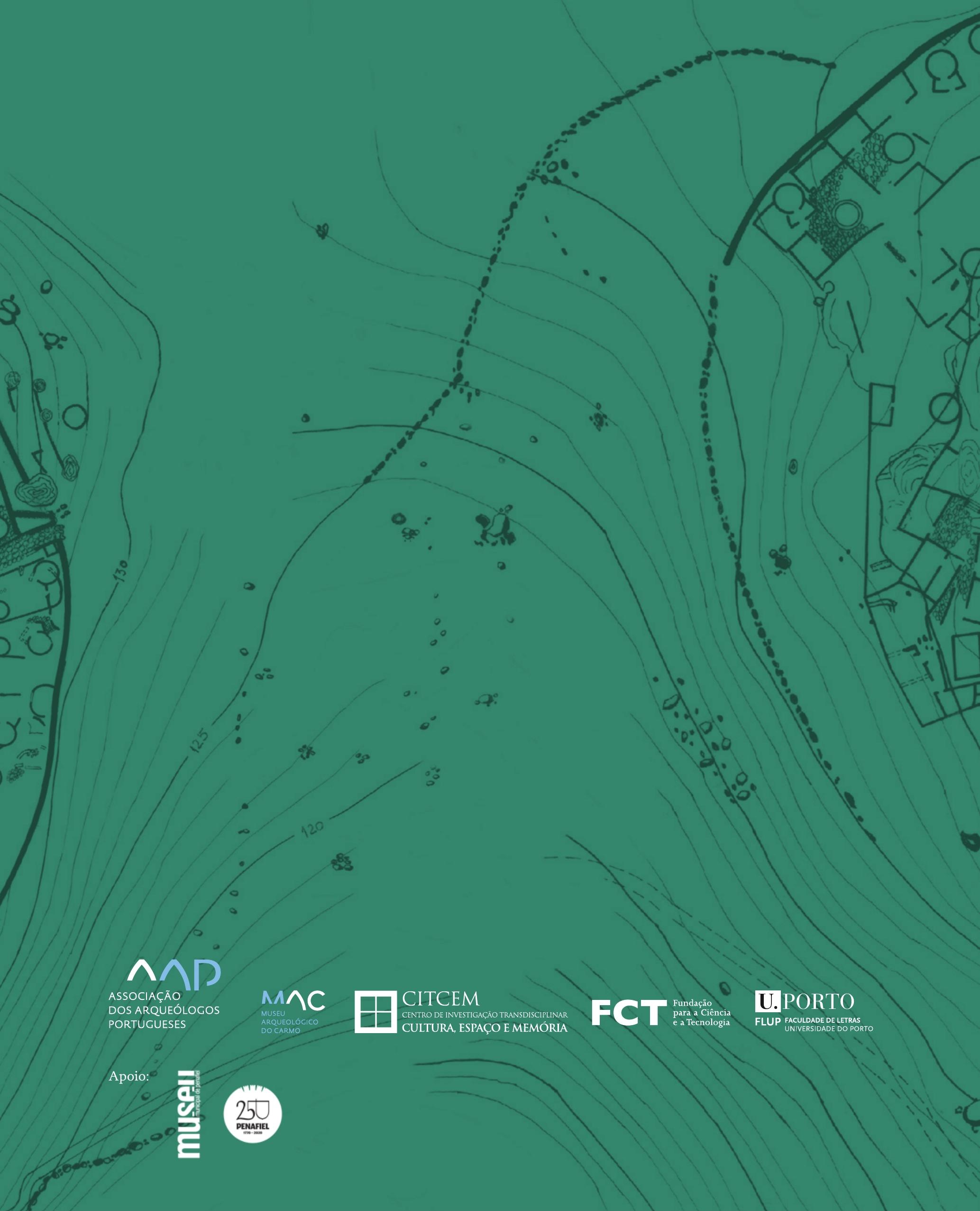

